\title{
No Imposition of Religion: The Establishment
}

\section{Clause Value}

\author{
Alan Schwarz†
}

The establishment clause of the first amendment ${ }^{1}$ has been interpreted to prohibit any aid to religion..$^{2}$ The free exercise clause has been interpreted to require that religious exercise be preferentially aided." The coexistence of these interpretations makes conflict between the clauses inevitable. For example, it is arguable that the establishment clause invalidates military service exemptions granted conscientious objectors, while the free exercise clause compels them. Since religious opposition is the only statutory basis for a conscientious objection claim, ${ }^{4}$ a religious belief is clearly being preferentially aided. Failure to grant the exemption, however, might violate free exercise.

The Supreme Court has usually decided religion cases on the basis of one clause or the other, without explicitly recognizing the potential conflict between them. Only Justices Brennan and Stewart have spoken to the seeming paradox, Brennan proposing that it be resolved by a subordination of establishment to free exercise, 5 Stewart proposing a less "wooden," "sterile" interpretation of the establishment clause." One commentator has proposed a merger of the two clauses into a united "neutral" principle, ${ }^{7}$ but most have favored a subordination or balancing approach. ${ }^{8}$ Part I of this Article will discuss unification,

$\dagger$ Professor of Law, Ohio State University College of Law. LL.B. 1955, Columbia University.

This article is based upon the 1967 Ohio State University College of Law, Law Forum Lecture Series, delivered by the author. The author wishes to state his appreciation for the student research assistance contributed by Mrs. Betsey Brewster Case.

I. The first amendment to the Constitution, now applicable to the States, Cantwcll $y_{1}$ Connecticut, 310 U.S. 296 (1940); Illinois ex rel. McCollum v. Board of Educ., 333 U.S. 203 (1948), provides:

Congress shall make no law respecting an establishment of rcligion or prohibiting the free exercise thereof. ... .

2. Everson v. Board of Educ., 330 U.S. 1, 15 (1947).

3. Sherbert v. Verner, 374 U.S. 398, 406 (1963).

4. Military Selective Service Act of 1967, § 6(j), 50 App. U.S.C.A. \& 456(j) (Supp. 1967)

5. Abington School Dist. v. Schempp, 374 U.S. 203, 299 (1963) (concurring opinion)

6. Sherbert v. Verner, 374 U.S. 398, 414 (1963) (concurring opinion); Abington Scliool Dist. v. Schempp, 374 U.S. 203, 317 (1963) (dissenting opinion).

7. Kurland, of Church and State and the Supreme Court, 29 U. Cill. L. REv, 1, 96 (1961), republished as P. KURLAND, RELIGION AND THE LAW (1962).

8. E.g., Fellman, Religion in American Public Law, 44 B.U.L. REv. 287 (1964); Gian. nella, Religious Liberty, Nonestablishment, and Doctrinal Development, 80 HaRv, L. REv. 1381 (1967); Katz, Freedom of Religion and State Neutrality, 20 U. CHI. L. REv. 426 (1958); Kauper, Church and State: Cooperative Separation, 60 MicH. L. REv. 1 (1961); Kauper, Prayer, Public Schools \& the Supreme Court, 61 Mich. L. REv. 1031 (1963); Moorc, The 
balancing and subordination as means of resolving the paradox. Part II will seek to demonstrate that, for the most part, the dilemma results from an unnecessarily broad reading of the establishment clause; that the clause should be read to prohibit only aid which has as its motive or substantial effect the imposition of religious belief or practice; and that the Supreme Court's decisions and much of its language are consistent with this proposed standard.

An imposition standard, by identifying the core value of the establishment clause, would clarify the issues. It would not, however, provide automatic answers. For instance, the question whether providing textbooks to parochial schools or school children constitutes aid to a religious function would not be dispositive, since aid to a religious function is constitutional so long as no imposition results. Consequently, in the absence of any imposition effect, provision even of religious books, although clearly aiding a religious function, would be valid. But whatever its form, state aid to parochial schools or school children may free funds for proselytization which in turn may result in imposition. This illustration suggests the need for distinctions within an imposition principle. We shall want to distinguish among situations where state aid to religion does not result in any substantial imposition, where the state itself imposes religion, and where the state aids the imposition efforts of private institutions.

I. Proposals To Resolve the Establishment-Free Exercise Paradox

\section{A. A No-Religious-Classification Standard}

Inconsistency between the establishment and free exercise clauses is avoided by merging them into a unified principle; each clause is thereby deprived of any independent content and inconsistency becomes impossible. Professor Kurland urges that both clauses should be construed as a unit to express the single principle that "religion may not be used as a basis for classification for purposes of governmental action whether that action be the conferring of rights or privileges or the imposition of duties or obligations."o The Supreme Court has not adopted a no-religious-classification principle. In the Zorach $^{10}$ and Arlan's Department Store ${ }^{11}$ cases it upheld preferential

Supreme Court and the Relationship Between the "Establishment" and "Free Exercise" Clauses, 42 TExAs L. REv. 142 (1963); Note, The Free Exercise and Establishment Clauses: Conflict or Coordination, 48 MinN. L. REv. 929 (1964).

9. Kurland, supra note 7 , at 5 .

10. 343 U.S. 306 (1963). 
treatment accorded religion and its exercise, and in Sherbert $v$. Verner ${ }^{12}$ and In re Jenison, ${ }^{13}$ applying the free exercise clause, the Court invali dated state action because preferential treatment had not been accorded religious exercise. ${ }^{14}$ Nonetheless, this paper will probe the principle because, if sustainable, it would provide substantial symmetry and certainty to applications of the religion clauses, and because the Supreme Court has not analyzed the principle or provided reasons for rejecting it.

Professor Kurland characterizes a no-religious-classification standard as "akin" to the equal protection clause..$^{15} \mathrm{It}$ is akin to rather than identical with equal protection, because it forbids all religious classifications instead of forbidding only all unreasonable religious classifications. A pure equal protection test would recognize the legitimacy of values other than perfect equality and consequently would require a determination of the reasonableness of a particular religious classification in terms of other free exercise and establishment values. Since accepting such additional values has resulted in an inconsistent interaction between the religion clauses, however, the use of a pure equal protection test would bring us full circle back to the existing dilemma. A no-religious-classification standard avoids the dilemma by treating the value of perfect equality as one of transcendent significance. Parndoxically, however, because the perfect equality concept is applied only to religious classifications, the standard often in fact discriminates against religious activities, and to that extent thereby subverts the principal value purportedly promoted by the standard. ${ }^{10}$ And where application of the standard satisfies the equality value, more significant establishment values are often subverted.

\section{The Inequality of No Religious Classification}

A no-religious-classification standard prohibits government from preferentially aiding religious activity. Aid may only be granted where the religious activity falls within a broader secular classification. The

11. Arlan's Dept. Store, Inc. v. Kentucky, 371 U.S. 218 (1962) (dismissing appeat for want of a substantial federal question).

12. 374 U.S. 398 (1963).

13. 375 U.S. 14 (1963).

14. In Sherbert all of the opinions recognized the state's right to single out religion for preferential treatment, the dissent differing only with respect to its obligation to do so.

15. Kurland, supra note 7 , at 5 .

16. See id. 96. 
standard thus insists that perfect equality be accorded nonreligious activities, with the result that a legislature may never consider a religious activity to be more worthy than a lawful nonreligious activity having an identical need for aid or protection. Consider application of the standard to an ordinance prohibiting raucous noises within 100 feet of a church, enacted in order to insure tranquility for religious observance. In that form the ordinance would be a religious classification, a religious activity having obviously been singled out for aid. Nor would this infirmity be remedied by extending protection to, say, hospitals and schools, if other activities requiring tranquility have not been included. If all activities with an equal need of protection were included, then the statute would make an activities-requiring-silence classification, which would not conflict with the standard. But short of such total coverage the statute does no more than list the activities to be protected; it provides no overall classification but, rather, separate church, hospital, and school classifications, and thus it seems inescapably to make, inter alia, a religious classification. Thus it would seem that a religious classification could be avoided only by extending protection to all lawful activities, regardless of their worth, which have an equal need of protection. In order to protect religious observance it would be necessary to protect the chess club or perhaps even the lawfully conducted poker game, assuming that both these activities require, for their enjoyment and efficiency, as few distractions as does a religious observance.

Moreover, the standard limits application of the perfect equality value to religious classification; all others are governed by conventional equal protection criteria. A legislature may grant protection to a hospital or school without extending identical aid to the chess game or, at least so long as most secular activities with an equal need for protection are not included, to religious observance; and this nonreligious classification may be made solely on the basis of a judgment of worth, since that factor, like need, is a reasonable basis for discrimination so long as no religious classification is involved. The standard, then, only guarnntees that secular activities will benefit if a religious activity is aided; it does not prohibit singling out a particular secular activity for preferential treatment. In prohibiting religious classification and simultaneously allowing hospital, school or chess club classification, the standard, in the name of equality, saddles religion with a disability not shared by secular activities and is thus inconsistent with the goal of equality.

The inequality produced by a no-religious-classification standard is apparently, but only apparently, neutralized by a special immunity 
granted religion. Unlike other activities, religion may never, regardless of rational reasons therefor, be specially obligated.17 Even if the standard did provide a special immunity, it is not clear why its price should be disability from special aid. In fact, however, the apparent special immunity is illusory. Application of a general regulatory or criminal law to injurious activity engaged in as a religious exercise would not be a religious classification but an injurious activity classification. Consequently, the standard shields religion only from state action penalizing belief or singling out religiously motivated injurious action for special punishment. But freedom of belief is independently protected by the free speech clause of the first amendment, ${ }^{18}$ and purposeful discrimination against religious activity is prohibited by the fifth and fourteenth amendments. Hence, a no-religious-classification standard results in a special disability upon religion without offering any meaningful compensatory special advantage.

\section{The Equality of No-Religious-Classification}

A no-religious-classification standard prohibits preferential aid to religion under all circumstances; it thereby results in inequality. At the same time, however, the standard requires that if all secular activities with a common characteristic receive aid, religious activities possessing that quality shall also benefit. Thus, if all secular activities requiring tranquility are protected, the religious observance must also be protected. Failure to extend the benefit to the religious activity in that situation would constitute a religious classification. To that extent the standard promotes equality, but in various applications it does so at the expense of a substantial establishment value.

Consider a board of education plan to include in the kindergarten curriculum by way of practice and illustration those activities which most children daily perform in their home lives. Such activities would include eating, bathing, dressing and, in particular communities, praying. A no-religious-classification standard would not only permit but also require that prayer be illustrated and practiced by all the children. The category aided is children's predominant at-home activities, a non-

17. This special immunity, even if it had any real content, would be, in the context of contemporary problems, quixotic. The controversies in the religion area, e.g., released time, Bible reading in the public schools, and exemption from tax, criminal and regulatory laws, involve special aids to religion and not special obligations. See Pfeffer, Religion-Blind Government, 15 STAN. L. REv. 389 (1963).

18. West Virginia State Bd. of Educ. v. Barnette, 319 U.S. 624 (1943); Picrce v. Soclety of Sisters, 268 U.S. 510 (1925); Griswold v. Connecticut, 381 U.S. 479 (1965). 
religious classification. The fact that a religious activity is a predominant at-home activity and is consequently aided would, under the standard, be irrelevant. The nonreligious class could not be parsed to exclude the religious activity; parsing would destroy the nonreligious character of the classification and defeat the standard's goal of equality. The class, predominant at-home activities, could therefore not be amended to exclude activities offensive to the religious beliefs of any of the children. An amendment excluding activities offensive to any of the children for any reason, religious or otherwise, would be permissible as a nonreligious classification, but the standard, although permitting, does not require such an exclusion. As a result of the exclusive focus upon the equality value, the standard ignores an establishment value more important than and inconsistent with equality. Thus, in the foregoing hypothetical, a violation of the establishment clause should be found in the imposition of religion by induced prayer whether prayer were given preferred or merely equal treatment.

It might be argued that this illustration sets up something of a straw man since, regardless of the applicability of the religion clauses, compulsory prayer is unconstitutional as a violation of the freedom to believe which is, under the vague teaching of West Virginia Board of Education v. Barnette, ${ }^{19}$ a right penumbral to freedom of speech. Even if such a penumbral right exists, however, it includes only freedom from coercion, not freedom from propaganda or other influence. Without reference to the religion clauses, the State may be prohibited from coercing belief or adherence to belief, even where the belief in question is patriotism, but nothing in Barnette prevents it from attempting to influence belief by propagating patriotism. This is so because although "penumbral radiations" of the free speech clause may prohibit coercing patriotism, that clause does not prohibit the establishment of patriotism. Hence, in order to invalidate a noncoercive prayer program included within a nonreligious classification, it is necessary to ascribe to the establishment clause greater content than Professor Kurland's standard gives it.

If the standard is modified to invalidate all direct government proselytizing, whether or not pursuant to a religious classification, its resulting applications, although less extreme, would still contravene the establishment value. Under such a revised standard, secular aid could and

19. West Virginia State Bd. of Educ. v. Barnettc, 319 U.S. 624 (1943). See also Griswold v. Connecticut, 381 U.S. 479 (1965). 
indeed must be granted to religious institutions on a nonpreferential basis where those institutions are as qualified as secular institutions to act as instrumentalities or conduits of a nonreligious government program. Consider a government program subsidizing the construction and operation of privately operated recreation facilities for underprivileged children. The program might properly exclude from participation organizations which are inexperienced in the operation of such facilities or have insufficient resources to finance unsubsidized costs. But the standard requires that religious institutions, if otherwise qualified, be eligible for participation. In practical operation only the established, wealthy sects would qualify. Since recreation facilities are probably as effective a means of proselytizing children as religious tracts, ${ }^{20}$ not only would the subsidy, compelled by the standard, have the ultimate effect of imposing religion, thus meeting the criterion of establishment violittion proposed in this article, but it would also favor imposition of the beliefs of the dominant, activist religions and hence effect a discrimination between religions.

In the foregoing example a no-religous-classification standard achieves equality at the expense of the establishment value. The resulting equality, moreover, benefits the religious institution, not the religious child. Subsidization of recreation facilities operated by religious institutions is not necessary to avoid discrimination between the religious and nonreligious child. There is no reason to assume that the religious child will not take advantage of a purely secular basketball court. But why should equality between secular and religious institll* tions-an equality made necessary by a no-religious-classification standard-be a constitutional imperative when discrimination between those institutions does not result in meaningful discrimination between their members? It is true that every organization has a point of view which may be subtly communicated in even the most innocuous activities, and that aid to the institution may advance its propagation efforts. The Constitution, however, does not prohibit the establishment of all points of view, but only of religious beliefs. And while the religious institution may rationally fear preferential, or indeed any aid to the antireligious institution for the reason that aid in any form may promote antireligionism, it seems absurd, except with respect to all-

20. See Shaper, School Aid: A Threat to the Parish, 82 Ciristian CEnTum 894.96 (1965); testimony of Reverend Lowell, Executive Director of Protestants and Other Ancricans United For Separation of Church and State, Hearings on S. 2097. Before the Subcomm. on .Constitutional Rights of the Senate Comm. on the Judiciary, 89th Cong, 2d Sess., pt. 2, at 748 (1966). 
encompassing activities such as education, to equate a nonreligious, secular viewpoint with antireligion, or to characterize it as a competing, secular religionism. Since equality between religious and secular institutions is not always necessary to prevent discrimination against religion or its adherents, and since equal treatment may aid a church in its proselytizing function and thus threaten an imposition of religion, the equality goal should not be elevated into a transcendent value underlying the religion clauses.

\section{The Proper Role of the Equality Value in Establishment Cases}

There are situations where according unequal treatment to religious and secular institutions does result in meaningful discrimination against religion or its adherents. Denial of government aid to parochial schools, for instance, results in three distinct injuries:

First, it obviously deprives the child attending parochial school of educational facilities equal to those accorded public school children. If aid to parochial schools constitutes an establishment violation, then of course its denial, being constitutionally compelled, would be a reasonable, albeit religious, classification and hence proper. But if, as we shall argue, ${ }^{21}$ such aid presents at most, a marginal, indirect danger of imposition, then under the standard we propose it may not be an establishment violation at all. Whether it is or not depends on a balancing of the denial of educational facilities resulting from discrimination, together with the public interest in quality education for all,22 against that marginal imposition danger.

Second, denial of aid to parochial schools discourages some Catholic children from attending them, since the public schools, with their greater resources, can provide a better education. Although the free exercise clause does not require government to render affirmative aid to religion, ${ }^{23}$ it may prohibit a general public aid program which fails to make allowance for, and thus discourages, a religious choice. Thus, in Sherbert v. Verner the Court held that although South Garolina had no constitutional obligation to instate a welfare program providing benefits to Seventh-day Adventists whose religious beliefs precluded gainful employment, it was nonetheless obligated to administer the general unemployment compensation program it had in fact adopted so

21. See pp. 736-37 infra.

22. See Hutchins, The Future of the Wall, in TuE Wale Between Churai aNd State 17 (D. Oaks ed. 1963).

29. Abington School Dist. v. Schempp, 374 U.S. 203, 299 (1963) (concurring opinion of Brennan, J.). 
as not to deter the faithful exercise of Seventh-day Adventism. ${ }^{24}$ By analogy, it is arguable that although a state need not allocate any funds for education, once it has done so it must not require any citizen to sacrifice his religious beliefs in order to obtain an equal education. ${ }^{25}$ Thus, although denial of aid to parochial schools may not constitute a clear free exercise violation, it does give rise to a substantial free exercise claim ${ }^{26}$ which, together with the Catholic's claim to equal facilities and the state's interest in excellent education for all children, ought to be balanced against the marginal imposition effect of aid.

Third, denial of aid to parochial schools, purportedly justified or compelled by establishment clause considerations, may itself impair the establishment value. The broad scope of the public school curriculum, the intense effect that curriculum has and is intended to have upon the value structure of all public school children, ${ }^{27}$ and the rigidly secular viewpoint there emphasized, provide some support to the contention that a secular religionism or antireligionism is being taught there, ${ }^{28}$ thus working a discrimination against at least all deistic religions. For example, to avoid preferring either Catholicism or Protestantism, a public school discussion of the Reformation would stress the political, social and economic bases of the movement, deemphasizing the doctrinal religious controversy; and to the extent that the theological dispute were considered it would be treated in an even-handed, neutral manner, as a subject upon which reasonable men may reasonably differ. This secular treatment unavoidably tends to belittle both Protestant and Catholic dogma and hence may perhaps be characterized as indoctrinating antireligionism or secular religionism. Similarly, a civics class in racial discrimination would invoke the equality value but would ignore its religious source, associating the value with Americanism or some other secular ethic. Ignoring the theological source of the imperative-and, worse, supplying an alternative secular sourcetends to belittle, perhaps even negate, the theological. Religion is most

24. 374 U.S. 398,410 (1963)

25. But see Everson v. Board of Educ., 330 U.S. 1, 16 (1947): "While we do not mean to intimate that a state could not provide transportation only to children attending public schools ...."

26. Everson v. Board of Educ., 330 U.S. 1, 58.59 (1947) (dissenting opinion of Rutledge, J.).

27. Cf. Illinois ex rel. McCollum v. Board of Educ., 333 U.S. 203, 216.17 (1948) (concurring opinion of Frankfurter, J.).

28. Drinan, The Constitutionality of Public Aid to Parochial Schools, in THE Wul. Between Church and STATE 55, 68.71 (D. Oaks ed. 1963); Murray, Lau or Prepossessions, 14 LAW \& CONTEMT. ProB. 23, 39 (1949). 
necessary, and hence most believable, when it provides the sole explanation for all phenomena. A system which provides answers without reference to religion or which teaches that there are no answers makes religion less necessary, and hence less believable. 20

The state, then, cannot be neutral in its operation of the public schools: It must either give equal time to a religious perspective upon so-called secular subject matter, in which case a discrimination between religions is inevitably effected, ${ }^{30}$ or it must limit itself to secular frames of reference, thereby belittling religion and offering itself as religion's competitor. The decision in favor of a purely secular curriculum represents, in establishment terms, a choice of general antireligionism as an evil lesser than the alternative of discrimination between religions. Although that choice may be wise it is not neutral. Viewed in this context, aid to parochial schools does not constitute a deviation from neutrality but an attempt to balance the antireligionism of the public school with the religionism of the parochial school or, from another perspective, to give parents an effective choice between a religious and antireligious education for their children. Another dilemma is created if aid to parochial schools, in part justified by the goal of neutrality, results in an imposition of religion perpetrated by the aided institution; aid in some measure neutralizes the state's imposition of antireligion but promotes the imposition efforts of the aided institution. It will be argued, however, that such aid presents only a marginal, indirect danger of imposition, qualitatively different from those threatened by a uniform, secular educátional system. ${ }^{31}$

\section{B. Balancing and Subordination Standards}

1. Balancing a Secular Purpose Against an Aid to Religion

In broad dictum Everson v. Board of Education construed the establishment clause as prohibiting all government aid to religion. ${ }^{32}$ To avoid the stark results reached by rigid application of a no-aid standard, various devices which limit the sweep of the principle have been

29. Cf. W. LippaAnN, A Preface to Morals (1929).

30. Abington School Dist. v. Schempp, 374 U.S. 281-83 (1963) (concurring opinion of Brennan, J.).

31. See pp. 736-37 infra.

32. 330 U.S. 1 (1947). "The 'establishment of religion' clause of the First Amendment means at least this: Neither a state nor the Federal Government can set up a church. Neither can pass laws which aid one religion, aid all religions, or prefer one religion over another. ... No tax in any amount, large or small, can be levied to support any religious activities or institutions, whatever they may be called, or whatever forn they may adopt to teach or practice religion." Id. at 15-16. 
adopted or proposed. Everson itself held that aid to religion was permissible where it was incidental to a state purpose to implement a secular goal and where the aid incidentally rendered religion was in. substantial. And, similarly, the Court's opinion in Abington School District $v$. Schemp $p^{33}$ states that an aid program incidentally advancing religion is permissible where the purpose of the program is exclusively secular and its effect predominantly secular..$^{34}$

The root defect of the balancing technique employed in Everson and stated in Abington is its failure clearly to identify and analyze the evil resulting from an aid to or advancement of religion. Balancing is a difficult and uncertain technique even when the identity and magnitude of all relevant values are clear. In the absence of an analysis of the precise evil resulting from aid and the magnitude of that evil it is impossible to balance intelligently a secular against a religious effect; consequently the standard neither explains nor predicts the results it reaches. For instance, in Everson a secular effect of the program was greater safety for all school children. An incidental aid to religion was the possibility that free transportation would increase attendance at parochial schools. Assuming, for the moment, that state action which increases parochial school attendance is an evil, it is still impossible to weigh the safety factor against that evil unless its nature and magnitude is understood. Suppose that reliable evidence demonstrated that free transportation would increase parochial school enrollment by 20 per cent and reduce accidents among parochial school children by one tenth of one per cent. Without an understanding of the quality and dimension of the threat presented by the parochial school or by govern * ment aid to the parochial school, the "primary" effect cannot be identi fied. In this context, Mr. Justice Black's dictum that free transportation "approaches the verge of ... power," 35 while perhaps helpful as an arbitrary touchstone, adds nothing to one's attempt to understand the Everson balancing technique or to apply it in a principled manner. More substantial aid than free transportation would have a greater

33. 374 U.S. 203 (1963).

34. "The test may be stated as follows: what are the purpose and the primary effect of the enactment? If either is the advancement or inhibition of religion then tho cnact. ment exceeds the scope of legislative power as circumscribed by the Constitution. That is to say that to withstand the strictures of the Establishment Clause there nutust be a secular legislative purpose and a primary effect that neither advances nor inhibits religion." Id. at 222 .

35. Everson v. Board of Educ., 330 U.S. 1, 16 (1947). The Court, in its present t(1II, has again upheld (sub silentio) the constitutionality of a transportation subsidy fort parochial school children. Rhoades v. Abington School Dist., 389 U.S. 11 (1967) (dismisse ing appeal for want of a substantial federal question). 
effect in enhancing the attractiveness of parochial schools, but such aid might also make a greater contribution to secular purposes. ${ }^{36}$

Similar difficulties exist in reconciling McGowan $v$. Maryland ${ }^{37}$ with a balancing standard. There, the compulsory Sunday closing law undoubtedly had the effect of increasing attendance at Sunday church services, seemingly an aid to and advancement of religion. Although the Court found that the contemporary purpose of the Maryland law, to provide a uniform day of rest, was exclusively secular, a correct application of the standard would have required a balancing of the state's interest in a uniform day of rest against the incidental aid to religion. Since the secular interest in "togetherness" would seem to be something less than compelling, ${ }^{38}$ certainly less compelling than children's safety, and since the supposedly incidental religious effect was pronounced, certainly more pronounced than the relationship between free transportation and parochial school attendance, the Court might have been expected to hold that the state had gone beyond "the verge of power" in requiring Sunday closing. Perhaps to avoid this problem, Chief Justice Warren's opinion upholding the statute all but ignores the pronounced religious effect. In fact, as will be discussed in Part II, review of Sunday closing laws should not call for any balancing, since the aid thereby rendered religion does not impair any constitutional value and hence is valid even in the absence of a greater secular good. The no-aid rule, however, starts with the assumption that any aid to religion is suspect and is only justified if incidental to a more important secular purpose and effect. It does not provide a criterion whereby a particular kind of incidental religious effect, albeit pronounced, may be judged less dangerous than a less pronounced but different kind of religious effect. McGowan, therefore, is either an arbitrary application of the balancing technique as measured by the arbitrary touchstone provided by Everson, or represents a departure from that technique. The basic difficulty, again, is that failure to explicate the evil of aid prevents anything but an arbitrary application of the balancing approach to the no-aid standard.

The inadequacy of a standard which balances secular benefits against aid to religion is strikingly demonstrated by its application to state

36. Everson v. Board of Educ., 330 U.S. 1, 50 n.42 (1947) (dissenting opinion of Rutledge, J.).

37. 966 U.S. 420 (1961).

38. Braunfeld v. Brown, 366 U.S. 599, 614 (1961) (opinion of Brennan, J., concurring in part and dissenting in part); id. at 616 (dissenting opinion of Stewart, J.); MfcGowan v. Maryland, 366 U.S. 420, 575-76 (1961) (dissenting opinion of Douglas, J.). 
action whose sole purpose and effect is to aid religion. The Everson and Abington formulations would make any such aid program unconstitutional, since there is no compensating secular purpose. But con* sider again the ordinance forbidding raucous noises within 100 feet of a church, or a church and other selected worthy institutions. Singling out religious, as well as other especially worthy activities, for preferential treatment represents a state judgment that those activities should be advanced. Protection of the tranquility of religious observance does not further any secular value and hence could not be justified by the Everson-Abington test. And yet, despite repeated statements of the primary-secular-purpose-and-effect test, the Court has sustained programs whose sole purpose is to aid religion, and it would undoubtedly sustain the raucous noise ordinance. The released time program in Zorach $^{39}$ had no other purpose, and even if Zorach is a unique case ${ }^{40}$ -a question to be examined-it is aberrant only in other respects, since subsequent to the Abington formulation of the test, the Court upheld per curiam a statute granting Sabbatarians exemption from a Sunday closing law, ${ }^{41}$ an exemption whose sole purpose could only have been aid to religion.

The deficiency of the secular balancing standard is its failure to identify the values protected by the establishment clause; thus it in. evitably equates qualitatively different aids to religion and results in chaotically inconsistent applications. To be sure, identification of the establishment values would not moot balancing in all cases. In some situations an important secular purpose may override a marginal, indirect threat of imposition of religion. ${ }^{42}$ The important point is that balancing can only follow, not replace, the first and essential task of determining whether state action threatens an imposition of religion, thereby creating prima facie evidence of an establishment violation.

\section{Subordinating Establishment to Free Exercise Values}

a. Constitutional Free Exercise

If a primary secular purpose and effect were the only permissible justification for aid to religious exercise, the free exercise clause would afford religion no greater protection than that accorded it under a no-religious-classification standard. No conduct could be excused be-

39. 343 U.S. 306 (1952).

40. Pfeffer, Court, Constitution and Prayer, 16 Rutgers L. Rev, 785, 749 (1962),

41. Arlan's Dept. Store, Inc. v. Kentucky, 871 U.S. 218 (1962) (dismissing appeal for want of a substantial federal question).

42. See pp. 731-37 infra. 
cause of its religious character, since excusal is obviously a form of aid, and preferential treatment accorded religious exercise serves a religious, not a secular purpose. Therefore, to the extent that the free exercise clause requires that religiously motivated activity receive preferential treatment, it either places the two religion clauses in irreconcilable conflict or compels a further modification of the no-aid principle.

Sherbert v. Verner ${ }^{43}$ involves this dilemma. South Carolina requires as a condition for receipt of unemployment benefits that applicants be available for suitable employment. Plaintiff, a Seventh-day Adventist, refused to accept weekly employment which included Saturday as a work day, and was consequently denied benefits. The Court held that the free exercise clause requires South Carolina to exempt Seventh-day Adventists from the Saturday availability requirement, finding no compelling state interest subverted by that exemption. Satisfaction of the free exercise claim by means of a Sabbatarian exemption would seem, however, to violate the establishment clause insofar as that clause prohibits preferential treatment of religion.4t

Justice Brennan, author of the Sherbert opinion, explains his method of resolving the dilemma in his concurring opinion in Abington:

[A]n increasingly troublesome First Amendment paradox [is] that the logical interrelationship between the Establishment and Free Exercise Clauses may produce situations where an injunction against an apparent establishment must be withheld in order to avoid infringement of rights of free exercise.t5

Thus in Sherbert the Court apparently subordinated the establishment to the free exercise clause. Somehow it balanced the constitutional right to exercise Sabbatarianism against the state's constitutional disability from aiding that exercise and concluded that the right was weightier than the disability. ${ }^{46}$ Indeed, the language quoted from Abington indi-

43. 374 U.S. 398 (1963).

44. Justice Stewart, concurring, makes the following point: "If the appellant's refusal to work on Saturdays were based on indolence, or on a compulsive desire to valch the Saturday television prograns, no one would say that South Carolina could not hold that she was not 'available for work' within the meaning of its statute. That being so, the Establishment Clause as construed by this Court not only permits but affrmatively requires South Carolina equally to deny the appellant's claim for unemployment compensation when her refusal to work on Saturdays is based upon her religious creed." 374 U.S. at 414-15 (emphasis in original).

45. 374 U.S. at 247.

46. Actually, the Sherbert opinion indicates that two separate balancings were performed. First, the exercise claim was balanced against South Carolina's interest in an efficient and easily administered unemployment compensation system in order to determine whether that claim should be considered a constitutional right; then, the resultant exercise right was balanced against the establishment disability. One wonders if the decision would have been the same if a different order of balancing were cmplojed. That 
cates that the Court may not have actually balanced right against disability, but rather assumed that when collision between the two religion clauses occurs, establishment is automatically to be subordinated to exercise.

Thus, in expanding the area of permissible aid to religion to include aid required by the free exercise clause as well as aid having a primary secular purpose and effect, Sherbert subordinated establishment to exercise. Moreover, it did so summarily, without explicit assessment of the relative importance of competing establishment and exercise values. But somehow the Court's cursory determination of priorities between constitutional clauses is not shocking or even surprising. It does not surprise because the establishment clause principle offered by Everson and its progeny-no aid to religion-seems to be an historical excrescence, properly subordinated to a contemporarily comprehensible "vital civil right." 47 The anachronistic quality of the no-aid principle, however, does not inevitably lead to a subordination standard. If the principle is senseless it is better discarded rather than merely subordinated. So viewed, Sherbert can be interpreted as rejecting rather than merely subordinating the no-aid principle. This interpretation avoids the doctrinal difficulties of subordination as well as the incongruity of two mutually inconsistent clauses in the same amendment. Moreover, redefinition avoids the danger that the establishment clause will be valued as something less than a vital civil right when it is used to protect against a meaningful establishment violation, i.e., an imposition of religion.

\section{b. Nonconstitutional Free Exercise}

As already noted, the no-aid principle, even as modified by secular balancing, does not accommodate the cases in which preferential aid has been accorded religious exercise. ${ }^{48}$ Nor would a subordination technique, at least of the sort the Court may or may not have used in Sherbert, explain these cases. The free exercise clause does not recpuirc either released time $e^{49}$ or exemption of Sabbatarians from Sunday

is, if instead of balancing the exercise claim against the state interest and then the resultant exercise right against the state's disability from satisfying it, the state's prima facie constitutional disability plus its interest in not satisfying the religious claim wore, in one weighing, balanced against that claim.

47. Giannella, supra note 8 , at 1389 .

48. E.g., Zorach v. Clauson, 343 U.S. 306 (1952); Arlan's Dept. Store, Inc. v. Kentucky, 371 U.S. 218 (1962) (dismissing appeal for want of a substantial federal question).

49. Cf. Stein v. Oshinsky, 348 F.2d 999 (2d Cir. 1965). 
closing laws.50 In order to reconcile Arlan's and Zorach, as well as existing but nonlitigated practices, with the no-aid standard, a further modification of that standard has been proposed. As further revised, the standard would permit the prima facie evidence of a violation represented by any aid to religion to be overcome by proof that the purpose of the aid was to protect free exercise, whether or not such protection is constitutionally required.01 Justice Brennan endorses this approach and urges it as a rationale justifying existing aids to religion, like army or prison chaplains or draft exemptions for conscientious objectors, which he assumes are not required by the free exercise clause. 52

A doctrinal difficulty with the religious purpose exception to the no-aid principle is its retention of "no aid" as a value to be weighed in determining the validity of aid. If no aid to religion is an establishment clause value, it is doctrinally absurd to override that value in the interest of serving its antithesis. Secular balancing, although deficient for other reasons, ${ }^{53}$ at least avoids this result. A constitutional value may often be overridden in order to serve an interest, such as children's safety, unrelated to the value. The religious purpose exception, however, justifies infringement of a constitutional prohibition by the value of infringing it. In other words, the religious purpose exception justifies a prohibited aid to religion by the value of aiding religion. But if the framers had thought that there was greater good in aiding religion than in denying it aid, they would not have prohibited aid. Since all aids to religion in some measure protect, promote or advance its exercise, a prohibition upon aid must represent a judgment that government should not protect, promote or advance exercise.

Sherbert-style subordination of an establishment violation to a free exercise right involves this same doctrinal difficulty, although there absurdity at least has the merit of warding off an apparent constitutional stalemate. In fact, however, the doctrinal problem precipitated by the religious purpose exception exists in the areas of both free exercise rights and free exercise claims only because the exception seeks to coexist with a no-aid principle. If that principle is discarded, no violation, prima facie or otherwise, results simply from an aid to

50. Braunfeld v. Brown, 366 U.S. 599 (1961); Gallagher v. Crown Kosher MIkt, 360 U.S. 617, 630 (1961).

51. Katz, supra note 8; Moore, supra note 8; Note, The Free Exercise and Establishment Clauses: Conflict or Coordination, 48 MIINN. L. REv. 929 (1964).

52. Abington School Dist. v. Schempp, 374 U.S. 203, 296-97 (1963) (concurring opinion of Brennan, J.).

59. See pp. 701-04 supra. 
religion. And if no imposition of religion is substituted for no aid in defining the content of the establishment clause, then aid to religion may be held invalid because it results in imposition but never simply because it results in aid.

In addition to the doctrinal difficulty, the religious purpose test cannot be intelligently applied. Like secular balancing, religious purpose fails to identify and assess the establishment values subsumed by the no-aid principle. The standard tells us, for instance, that released time is in some degree bad because it aids religion. It is also in some degree good because it protects or promotes religion. But unless we are told the specific evils of aid and the dimensions of those evils it is impossible to balance intelligently the good against the bad.

A possible means of balancing without identifying underlying establishment evils might be to formulate a rule which permits aid based upon a religious purpose only when that aid "protects" free exercise. 04 So phrased, the rule relies upon a distinction between a protection and an encouragement, enhancement or promotion of religious exercise: protection encompasses a basic minimum need, whereas the others are luxuries or at least nonessentials. A difficulty here is that there is in fact no necessary correlation between that which is most vital to free exercise and that which is least damaging to establishment values. The Jewish faith, for instance, requires a minimum of ten Jewish men as a quorum to conduct some vital religious services. The availability of ten Jewish men, then, is basic to the exercise of Orthodox Judaism. State action which coerced or even induced attendance at services in order to satisfy the "minyan" requirement would, however, be a clear imposition of religion and therefore impermissible regardless of need. A more basic difficulty is that, as so applied, the religious purpose standard prohibits aid which is not necessary to protect exercise but which may be valuable to religion and causes injury to no one. This application again results from the acceptance of no-aid as a meaningful establishment value. This assumption is challenged in Part II of this article.

\section{The No-Imposition-of-Religion Standard}

\section{A. Other Establishment Values}

The original meaning of the establishment clause is obscure. Madison may have believed in the complete separation of church and state, in. 
cluding a rigid no-aid principle, and may have incorporated that belief into his Memorial and Remonstrance. ${ }^{.5}$ It is doubtful, however, that even Madison intended the first amendment to accomplish such a complete separation, and it is more doubtful that the Congress which adopted and the states that ratified the amendment so intended.5 Partly because its original meaning is unclear and partly because of a modern jurisprudence which justifies departure from original, specific intent, ${ }^{57}$ the Court in interpreting the clause has relied primarily upon the historical and contemporary values which should structure the relationship between religion and government. ${ }^{53}$

It is agreed that the establishment clause prohibits government from intentionally creating an official or preferred religion; ${ }^{53}$ at this point agreement ends. Some contend that the clause does not prohibit anything except an official or preferred religion; ${ }^{20}$ others that the clause effects a wall of separation, to be breached only by a secular or religious value weightier than the separation principle. ${ }^{01}$ The latter position is subsumed under the phrase "no aid to religion." The validity of the "no-aid" principle is the essential controversy arising under the establishment clause, and the various attempts to create devices to soften the impact of that principle without abandoning it are responsible for the confusion in the area. The question then arises: why shouldn't government aid religion? Several reasons, purportedly of constitutional dimension, have been given.

55. Murray, supra note 7 , at 30 .

56. W. MARnwell, The First AMendarent 111-13 (1964); Corwin, The Supreme Court as National School Board, 14 LAw \& Conteasp. Prob. 3, 13 (19:9); Areiklejohn, Educational Cooperation Between Church and State, 14 LAw \& Costram. P5OD. 6l, 71 (1949); Murray, supra note 28, at 27-28. But of. C. ANTEAU, A. Downex \&. E. Ronerts, Freenoos FROM FEDERAL ESTABLISHMENT 29, 91, 121, 197 (1964); Cahn, The Establishment of Religion Puzzle, 36 N.Y.U.L. REv. 1274, 1279-81 (1961); Konvitz, Separation of Church and siate: The First Freedom, 14 Law \& Contenip. Prob. 44, 55.56 (1949).

57. A. Bickel, The least Dangerous Branch 16 (1962); C. Black, Tue Occasions of JUSTICE 192 (1963).

58. "Whatever Jefferson or Madison would have thought of Bible reading or the recital of the Lord's Prayer in what few public schools existed in their day, our use of the history of their time must limit itself to broad purposes, not specilic practices." Abington School Dist. v. Schempp, 374 U.S. 203, 241 (1963) (concurring opinion of Brennan, J.); milinois ex rel. MicCollum v. Board of Educ, 333 U.S. 203, 212-13 (1947) (separate opinion of Frankfurter, J.).

59. See, e.g., R. Drinan, Religion, the Courts and Public Policy 223 (1963); A. Stones \&. L. PFeffer, Church AND STATE IN THE UNTted States 100.03 (1964); Katz, supra note 8, at 434; Moore, supra note 8, at 154-55.

60. Corwin, The Supreme Court as National School Board, 14 Law \& Contzur. Pros. 3 (1949); Fahy, Religion, Education and the Supreme Court, 14 LAW \& Costeas. Pros. 73 (1949); Meiklejohn, supra note 56; Murray, supra note 28.

61. L. Pfefrer, ChuRch, State AND FrefDos 727 (1967); Handy, The American Tradition of Religious Freedom: An Historical Analysis, 13 J. PUB. L. 247, 259 (1964). See also authorities cited note 8 supra. 


\section{Aid Impairs Religious Liberty}

The first argument is that aid justifies regulation and regulation impairs free exercise. ${ }^{62}$ The argument is neither historically nor juridically correct. Government has always aided religion, nonpreferentially as in fire and police protection, and preferentially as in tax ${ }^{03}$ and draft ${ }^{64}$ exemptions. These aids have not in fact been accompanied by regulations which impaired free exercise. Moreover, if aid presented a constitutionally significant danger of infringing upon free exercise, nonpreferential as well as preferential aid should be invalid. To the extent that aid authorizes regulation, that regulation could as easily be affixed to one form as the other; yet even the most militant separationists would allow some forms of nonpreferential aid. ${ }^{05}$ Most importantly, aid does not justify any greater regulation of free exercise than would be permissible in the absence of aid. Where regulation is vital to a secular interest it may be justified by that secular interest alone; ${ }^{00}$ and where regulation is not vital, Sherbert and other unconstitutional condition cases $^{67}$, demonstrate that it may not be justified by aid. It is true that, as a political matter, aid may prompt constitutional regulation theretofore absent, but the aid has not, in that event, expended the legislature's power-it has only resulted in its exercise. This considerntion is relevant to the question of whether a religious institution should apply for aid; it is not relevant to whether the aid may be constitutionally granted.

\section{Aid Causes Strife}

The Court ${ }^{68}$ and commentators ${ }^{60}$ sometimes refer to avoidance of strife as an establishment clause value from which the no-aid principle

62. Everson v. Board of Educ., 330 U.S. 1, 53 (1947) (dissenting opinion of Rutledgc, J.); $i d$. at 26-27 (dissenting opinion of Jackson, J.); Fahy, Problems of Chutrch and state in the United States: A Protestant View, in The Wall Betwern Chiurch and State 26, 39 (D. Oaks ed. 1963); Kurland, supra note 7, at 4.

63. See generally Kauper, The Constitutionality of Tax Exemptions for Religious Ac. tivities, in The Wall BeTween Church and State, 95-116 (D. Oaks ed. 1963).

64. Military Selective Service Act of 1967, § 6(i); 50 App. U.S.C.A. $\S 456(j)$ (Supp. 1967). J.).

65. Everson v. Board of Educ., 330 U.S. 1, 60.61 (1947) (dissenting opinion of Rutledge,

66. Parochial school curricula, for instance, are regulated, although no aid is given to parochial schools. See, e.g., N.Y. EDuc. LAw \& 3204 (McKinney 1953):

Instruction Required

(1) Place of Instruction. A minor required to attend upon instruction by the provisions of part one of this Article may attend at a public school or elsewhere. The requirements of this section shall apply to such a minor irrespective of the place of instruction.

67. Garrity v. New Jersey, 385 U.S. 493 (1967); Spencer v. Randall, 357 U.S. 513 (1958).

68. Engel v. Vitale, 370 U.S. 421, 429 (1962); Everson v. Board of Educ., 330 U.S. 1, 8-11 (1947); id. at 26-27 (dissenting opinion of Jackson, J.).

69. Cahn, supra note 56, at 1290; Choper, Religion in the Public Schools: $A$ Proposod 
is derived. The strife to be avoided is apparently supposed to be caused by the antagonism of religious or irreligious groups who are not aided or who feel that others have received a disproportionate share. ${ }^{70}$ Since inequality in aid could, presumably, be remedied by a constitutional requirement of equality and since it is not suggested that unavoidable inequalities in aids to religion present peculiar constitutional dangers, proponents of this view apparently regard the bona fides of the grievance to be irrelevant. It is sufficient that aid does cause strife, whether or not that strife is rational.

To state this proposition is to ridicule it. If avoidance of strife were an independent constitutional value, no legislation could be adopted on any subject which aroused strong and divided feelings. Nor could a constitutional doctrine of strife avoidance be limited in application to legislation which exacerbates religious differences on the ground that those differences are more upsetting than any others. Patently, racial differences are today a far greater cause of strife than differences in religious belief. Would, then, the possibility of exacerbated racial controversy in and of itself invalidate open housing legislation?

Moreover, prohibiting aid to religion does not avoid strife, it merely alters its source. Aid to parochial schools may exacerbate strife by antagonizing Protestants who for the most part would not derive advantages from such an aid program. Failure to aid, however, antagonizes Catholics who pay taxes to support public school education and pay separately to educate their own children at parochial schools. Even if strife avoidance were an independent constitutional value, it would support a no-aid standard only if religious groups generally agreed to a no-aid principle. ${ }^{71}$ Since there is no such agreement, ${ }^{72}$ both aid and no aid cause strife. Consequently, one must look elsewhere for the source of the no-aid principle.

Constitutional Standard, 47 MrNw. L. REv. 329, 331 n.8 (1963); Fahy, Problems of Church and State in the United States: $A$ Protestant Piew, in The WALL Betwens CuUncil AND STATE 26, 38 (D. Oaks ed. 1963); Gordon, The Unconstitutionality of Public Aid to Paro. chial Schools, in id. 79, 77-78.

70. "Public money deroted to pajment of religious costs, cducational or other, brings the quest for more. It brings too the struggle of sect against sect for the larger share or for any. Here one by numbers alone will benefit most, there another." Everson v. Board of Educ., 330 U.S. 1, 53 (1947) (dissenting opinion of Rutledge, J.).

71. Indeed, even if there were such agrecment, failure to aid parochial schools would cause strife since many Catholics believe that in supporting the public schools they are subsidizing an alien religious or irreligious dogma. See authorities cited note 27 supra.

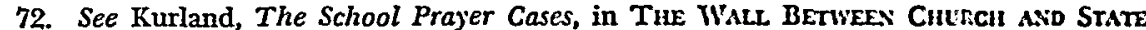
142-46 (D. Oaks ed. 1963) (reactions of religious leaders to the Supreme Court's decision in the Prayer Cases). 


\section{Aid Costs Money}

Most governmental aids to religion involve an expense which is borne in part by the nonbeliever and the other-believer, either indirectly through their tax bill, as in a subsidy to religion, or directly as in exemption of Sabbatarians from Sunday closing laws. ${ }^{\text {T3 }}$ The supposed inequity of this burden often is stated as the reason for the noaid principle. Justice Black, for instance, writes for the Court in Lverson, "No tax in any amount, large or small, can be levied to support any religious activities or institutions . . .,"74 and he cites the Virginin Bill For Religious Liberty for the proposition " that to compel a man to furnish contributions of money for the propagation of opinions which he disbelieves, is sinful and tyrannical." "75

Emphasis upon pocketbook injury suffered by the nonbeliever or other-believer suggests that the value being invoked is that public moneys cannot be used to support private purposes. Religion, it is assumed, is exclusively a private affair. Ergo, the government may not use public funds to aid religion. ${ }^{76}$ The minor premise of this syllogism, however, is false. ${ }^{77}$ Religion has significance to an individual in areas which may fairly be called private; it also has significance in areas which are of vital public concern. Successful government in the United States depends upon popular participation in the affairs of government and

73. The Sabbatarian exemption may cause financial injury to all those who, not being Sabbatarians, are forced to close on Sunday, thereby losing trade to their Sablat. tarian competitors.

74. Everson v. Board of Educ., 330 U.S. 1, 16 (1947). See also Abington Schoul Dist. v. Schempp, 374 U.S. 208, 299-300 (1963) (concurring opinion of Douglas, J.); Engel v. Vitale, 370 U.S. 421, 444 (1962) (concurring opinion of Douglas, J.); Everson v. Buard of Educ., 330 U.S. 1, 40-41 (1946) (dissenting opinion of Rutledge, J.).

75. Everson v. Board of Educ., 330 U.S. I, 13 (1947). Note, however, that the Virginia Bill emphasizes "propagation," not aid to exercise, as that which it is tyrannical to be compelled to contribute. This language seems more oriented to the fear of imposition than to a pocketbook interest.

76. Even if it were assumed that religion is exclusively a private affair, a construction of the establishment clause as limited to the protection of the pocketbook interests of non. believers and other-believers would not invalidate aid to parochial schools. Any stuch aid is nominally for a secular use, the allegation of religious use made by opponents of such aid programs being based upon the premise of inevitable partial diversion of funds to a religious use or the view that a parochial school cannot or will not separate secular from religious subject matter. Since such aid programs will, however, inevitably enhance secular education in the parochial schools, even if some of the moncys will be diverted to an exclusively religious use and even if there is an inextricable intermixture of reliyious and secular subject matter, the argument of the opponents resolves to the proposition that public moneys cannot be expended inefficiently. But cannot a legislature rationally conclude that an investment in a public purpose (secular cducation in the parochial schools) is worthwhile even if some of the moncys inevitably and irremediably will be used to advance a private but otherwise innocuous use? See notes 80 \& 84 infra.

77. Father Murray observes that the intuitive conclusion that religion is exclusively a private affair may well be used upon deistic belief which so defines man's relationship with God. To read that belief into the establishment clause, however, is to establish deism. Murray, supra note 28, at 29. 
in a thousand other affairs which are private only because individual and associational participation have made government intervention unnecessary. Some of this vitally necessary participation results from unalloyed self-interest (vote your pocketbook). Much of it, however, requires a sense of the rightness and wrongness of things-a sense indispensable to involvement where immediate self-interest is absent. One need not accept Kant's argument that God exists because true mornlity cannot exist without God in order to recognize that religion is important if not indispensable to a moral sense, that a moral sense is important to involvement, and that involvement is necessary to democracy..$^{78}$ Alexander Meiklejohn makes the point well:

$[T]$ hinking and feeling, though different from one another, are dependent on each other. What we feel and do about any object determines, and is determined by, what we know and believe about it. Any man or society whose feelings are going in one direction while his ideas are going in another is, in so far, lacking in sanity and heading for breakdown. ... For some 40 or 50 or 60 per cent of our people, ... religious belief is ... the necessary and sufficient source from which our democratic institutions derive their moral validity. ${ }^{79}$

Although religion promotes involvement and therefore serves a public purpose, ${ }^{80}$ there may still be reasons for prohibiting government from aiding it. But any such reasons would have nothing to do with public purpose; indeed if they exist, they do so despite rather than because of the relationship between religion and public purpose. And the Supreme Court, when it has directly addressed itself to this matter, has recognized the public aspect of religion rather than simply stating the major premise and conclusion of a defective syllogism. In Zorach the Court said, "We are a religious people whose institutions presuppose a Supreme Being"; 81 and in Engel v. Vitale, "T2 "The history of man is inseparable from the history of religion." Even Justice Rutledge recognized that religion promotes the public welfare; his vehement

78. See generally W. LIPPMAN, supra note 29.

79. Meiklejohn, supra note 56, at 62.

80. The aid-costs-money basis for the no-aid principle relies entirely upon the public purpose doctrine. To satisfy the requirements of that doctrine as it is elsewhere applicd it is not necessary to demonstrate conclusively a relationship between religion and public purpose but only to show that a legislature could reasonably believe that such a relationship exists. Ferguson v. Skrupa, 372 U.S. 726 (1963); Railway Express Agency v. New York, 336 U.S. 106 (1949).

81. 343 U.S. at 313.

82. 370 U.S. at 434 . 
objection to aid was based upon what he conceived to be its independent dangers. ${ }^{83}$

In any event, does the public purpose doctrine necessarily require a benefit to the state? Why may not satisfaction of a "private" need or" desire be a public purpose, when that need or desire will be frustrated without government aid and when the public considers it to be worthy (as it arguably considers religion)? Before the government can supply food stamps to starving Americans, must it first be shown that the economy will thereby benefit or that crime will be avoided or contagious disease prevented? Or isn't giving food to hungry people a sufficient public purpose?

Once it is recognized that aid to religion is aid for a public purpose, however that phrase is defined, the "why should I pay to support another's religious belief" argument loses all constitutional force. A taxpayer's lack of sympathy with the public use to which his funds are being applied is constitutionally irrelevant. The allocation of resources among competing claims, each serving a public purpose, is essentially a political question, ultimately to be determined by the electoral process, not the Constitution. ${ }^{84}$ Constitutional determination requires injury to a constitutional right, and the aid-costs-money basis for the no-aid principle, except as it seeks to rely upon the public purpose doctrine, is not based upon any such injury. ${ }^{85}$

Moreover, despite dicta disapproving of the expenditure of public money for religious use, the Court has not invalidated any aid to reli. gion on that basis. The issue was precipitated in almost crystalline form in Arlan's Department Store v. Kentucky. ${ }^{80}$ There the Court dismissed

83. Everson v. Board of Educ., 330 U.S. 1, 52 (1947) (dissenting opinion).

84. Williams v. Lee Optical, 348 U.S. 483 (1955) (and cases cited therein).

85. If the interest guarded by the establishment clause is not that of preventing the use of the nonbelievers' or other-believers' money for a religious purpose, but, as wo shall show, that of protecting against an imposition of religion, then a taxpayer's injury should always be an insufficient basis for standing to assert an establishment violation. $A$ tax. payer, in his capacity as a taxpayer, would always be asserting injury to a nonconstltt. tional interest or, at best, injury to another's constitutional interest. Theoretically, any case, e.g., Everson v. Board of Educ., 330 U.S. 1 (1947), which bases standing cxclusively on taxpayer status implies, to that extent, that the establishment clause protects a financial interest. Standing doctrine, however, has certainly not been consistently ap. plied, and no insight into the merits can be gained from a decision which assunics or explicitly recognizes a party's standing. Compare Tileston v. Ullman, 318 U.S. 44 (19.13) with Griswold v. Connecticut, 381 U.S. 479, 481 (1965) and Barrows v. Jackson, 846 U.S. 249 (1959). See also A. BICKEL, supra note 57, at 120-27; Lewis, Constitutional Rights and the Misuse of 'Standing,' 14 STAN. L. REv. 433 (1962). If, however, standing has any prin. cipled content, it should more easily be found where a party suffers injury to a religious interest than where the only injury is financial. See Abington School Dist. y. Schempp, 374 U.S. 203, 224 n.9 (1963); Black, Religion, 'Standing' and the Supreme Court's Role', 13 J. PuB. L. 459 (1964). See also Brown, Quis Custodiet Ipsos Custodes?-The School. Prayer Cases, 1963 SUPRENIE CourT REv. 1.

86. 371 Ú.S. 218 (1962). 
for want of a substantial federal question an appeal from a state court decision upholding legislation exempting Sabbatarians from the Sunday closing laws. The sole purpose of the exemption was to aid Sabbatarianism and it caused non-Sabbatarian store owners far more financial injury than any individual taxpayer indirectly suffers through a grant of public funds for a religious purpose. ${ }^{.7}$ Although the Court may have weighed an establishment clause prohibition against compelling anyone to support another's religion against the Sabbatarians' free exercise claim and arbitrarily concluded that the free exercise claim was weightier, ${ }^{88}$ the manner of disposition may indicate that the Court found no constitutional basis for the citizen's interest in not supporting another's religion.

\section{Aid Impairs Secular Unity}

Every level of government has an interest in the unity of its citizens. A shared system of values minimizes dissension and facilitates joint action toward a common goal. The best means of achieving unity is to reserve for government operation those institutions which exert the greatest influence on shaping the values of the population. Perhaps the most important of all such institutions is the educational system. Justice Frankfurter, concurring in Illinois ex rel. McCollum v. Board of Education," describes the public school as "[d]esigned to serve as perhaps the most powerful agency for promoting cohesion among a heterogeneous democratic people" and as "a symbol of our secular unity."90

Not all aids to religion meaningfully affect secular unity. Some-like exempting Mrs. Sherbert from unemployment compensation requirements ${ }^{91}$-are not relevant to the unity goal. Others-like exempting conscientious objectors from military service and providing army chaplains-may conceivably weaken the unifying tendencies of a secular institution. But the essential purposes of the military as an institution do not include the promotion of unity. Therefore, even complete acceptance of secular unity as a constitutional value need not yield a rigid no-aid standard. Some aids to religion, however, contravene the unity value by weakening secular institutions which significantly promote that value. Aid to parochial schools, for instance, will

87. See note 73 supra.

88. See pp. 706-09 supra.

89. 333 U.S. 203 (1948).

90. Id. at 216-17.

91. See pp. 705-06 supra. 
decrease the enrollment of Catholic children in the public schools and thus impair the unifying tendencies of that institution. And released time, while probably having the effect of increasing attendance of Catholic children at public schools and thus strengthening the institution, impairs its unifying effect.

On what basis, however, is it assumed that secular unity is a constitutional requirement? The state, to be sure, has a corporate interest in unity, but in no other context is a state corporate interest converted into a constitutional requirement. The state has an interest in an educated population. Is compulsory education, then, a constitutional mandate; and is a government program to employ school drop-outs, then, unconstitutional? The Constitution defines permissible governmental interests; it does not require that permissible interests be effectuated nor prohibit a legislature from impairing one in order to serve another permissible interest. The function of choosing between permissible but inconsistent interests, at least in every other context, is assigned to the legislature and ultimately, through the political process, to the people.

Since the state's interest in secular unity does not give rise to a constitutional prohibition against aid, the relationship between any such prohibition and the unity value must be based upon an individual constitutional right. But no such right is apparent. Aid to parochial schools, released time and prayer in the schools all, to one extent or another, impair unity, either by facilitating the segregation of children according to their religious or irreligious beliefs or by recognizing religious differences where there is no segregation. This characterization of the situation invites analogy to Brown v. Board of Education, 02 but here, unlike Brown, there is no state policy to segregate; that result is caused entirely by individual choice. A more appropriate analogyassuming that religious and racial segregation are analogous-is Griffin v. County School Board..$^{33}$ There, the Court invalidated a plan whereby the state subsidized attendance at racially segregated private schools. It did so, however, because of its conclusion that the purpose of the plan was to implement the state's policy of maintaining segregated schools and, significantly, the decree enjoined the subsidy only so long as the county public schools were closed. ${ }^{04}$ It cannot be seriously con. tended that in aiding parochial schools any state has been or would

94. Id. at $231,233$. 
be implementing a state policy to segregate according to religion, rather than respecting private individual choice and implementing a state policy of quality education for all children.

Even if the Constitution were to be interpreted to prohibit all aid which has the effect of impairing racial unity, regardless of state policy, ${ }^{95}$ the injury which would prompt such an interpretation is qualitatively different from any injury caused by the impairment of secular unity. In Brown, the evil of segregation was not that it impaired any abstract associational claim. Rather it was the psychological injury caused by a state policy of segregation carrying an implicit judgment of inferiority, coupled with the denial of equal educational benefits, which the Court found to be an inevitable result of racial school segregation. Regardless of the correctness of the Court's psychological and educational conclusions in Brown, they have no bearing on any injury caused by impairment of secular unity. That value by itself protects only the abstract associational claim of togetherness and a claim to have the concept of oneness inculcated through the public school curriculum. Aid to parochial schools, for instance, may result in depriving Protestant children of association with Catholic children, but the Protestant child's loss in no way resembles the injury which the Court in Brown found that segregation works on the Negro. That being the case, why is the Protestant's claim to association with the Catholic to be preferred to the Catholic's claim to disassociation ${ }^{30}$ And why does the Protestant have a constitutional right to have the Catholic exposed to the teaching

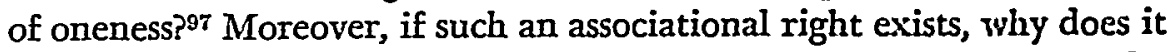
exist only with respect to religious differences? The economically deprived student would seem to have a greater associational interest in attending school with the wealthy student than a Protestant does with a Catholic. Yet neither the establishment clause nor any other provision in the Constitution prohibits aid to nonsectarian private schools. ${ }^{93}$

95. See Reitman v. Mulkey, 387 U.S. 369 (1967). The Reilman decision is diffcult to understand. Giving it the broadest reasonable reading, however, it would only stand for the proposition that a state may not act for the purpose of encouraging or authorizing private discrimination. Even accepting this very broad reading, state action, otherwise motivated, which incidentally facilitated private discrimination vould be valid.

96. See Wechsler, Toward Neutral Principles of Constitutional Law, 73 HANv. L. REv. I, 34 (1959).

97. Such a right might exist if the establishment clause represents a constitutional judgment that religion is antithetical to the constitutional rights of nonbelievers and other-believers. This possibility is discussed at pp. 721-24 infra.

98. See Griffin v. County School Bd., 377 U.S. 218 (1964); N.Y. Times, Sept. 7, 1967, at 1 , col. 5 (report that New York State Attorney General Lelkowitz will rulc that state professorial endowment grants to Fordham University-a Catholic institution-are violative of the New York State Constitution whereas such grants to other private universities are valid). 
Thus considered, neither the claim to association nor that to disassociation should be constitutionally preferred, and unless we can find a more persuasive establishment value, the state should be free to decide between these antithetical associational values according to which has the greater political support or which best coincides with a corporate state interest. One such interest is unity, but another is excellence in education for all. Yet another basis for a political decision is the religious claim of those wishing disassociation. The Court held in Pierce v. Society of Sisters ${ }^{99}$ that compulsory public school education was unconstitutional. This holding does not compel aid to parochial schools, although as a practical matter many Catholics will "have" to attend public schools if parochial schools are not aided, ${ }^{100}$ but the free exercise claim, ${ }^{101}$ like the correlative establishment claim precipitated by attendance at "secular" public schools, ${ }^{102}$ may properly be considered by a legislature in arriving at its determination.

That secular unity is not and should not be an establishment clause value is finally and perhaps best shown by the results it would authorize. To obtain maximum unity between the Catholic and non-Catholic populations the state would induce (though it cannot compel) Catholics to desert the parochial schools. So long as Catholic education funds hold out, the only inducement with any chance of success would be a system of voluntary religious training in the public schools. Offering religion in the public schools would deprive the parochial school of at least some of the advantages it now offers the religious Catholic, and the more religion offered, the greater the inducement. This solution might make a greater contribution to togetherness and the inculcation of oneness than public schools without religious training. To be sure, religion in the public schools would dilute the maximum togetherness now available to the children who attend them, but that dilution might well be more than made up for by exposing a larger percentage of the Catholic school community to much more togetherness and some more oneness than they now receive. Somehow this solution to the secular unity problem is not appealing. But, if the foregoing analysis is correct, its lack of appeal cannot be explained by its failure to promote secular unity. Rather, it demonstrates that secular unity is not the establish. ment value we are seeking.

99. 268 U.S. 510 (1925).

100. See note 147 infra.

101. See also pp. 699-700 supra.

102. See pp. 700-01 supra. 
5. Aid Impairs Equality Among Religions and Between Religion and Irreligion

Whatever additional content the establishment clause may have, it clearly prohibits discrimination among religions and between religion and irreligion. ${ }^{103}$ To the extent, horvever, that the agreed principle of no preference is analogous to the equal protection clause, it does not yield a derivative principle of no aid. It merely requires that if aid is granted, the aided category must include all religions and irreligions. So read, the establishment clause requires that aid be granted atheists and agnostics if Protestants and Catholics are aided. It does not, however, require as a condition of aid to religion that institutions or activities which have nothing to do with either religion or irreligion also be aided. A standard which allows aid so long as it is equal necessitates a constitutional definition of "religion" and "irreligion." The definitional problem is troublesome, ${ }^{10 \pm}$ but that difficulty does not justify" rejection of an equal-aid standard since the same difficulty inheres in a no-aid standard. "Religion" must be defined whether the standard be no aid or equal aid.

To substitute an equal-aid for a no-aid principle would not result in identical, and perhaps not even in equal, benefits. Legislators, judges and administrators may, improperly, define religion and irreligion according to their own beliefs, thus discriminating against irreligion and the minority, odd-ball sect. More importantly, identical benefits are often impossible to achieve. To allow each schoolchild in turn to recite a prayer or antireligious statement of his choosing, for instance, while satisfying the value of equal opportunity, would most benefit the majority belief since that belief would realize the most prayer time. Or, to grant financial aid to all religious and irreligious institutions will provide a lesser benefit to the minority sect which may not have the members, finances, organization, or even the desire to utilize the grant. The equality principle, however, does not demand identical benefit. Disparity in resultant benefits is an unavoidable characteristic of any aid program, and the equality principle, as conventionally understood, requires only that all members of the same class (i.e., all religions and irreligions) receive the same opportunities. Indeed, the conventional equality value demands that a religion with a large number of

103. Abington School Dist. v. Schempp, 374 U.S. 203, 216-17 (1963); Torcaso v. Watkins, 367 U.S. 488, 495 (1961); Zorach v. Clauson, 343 U.S. 306, 314 (1951); Everson v. Board of Educ., 330 U.S. 1, 15-16 (1946).

104. See United States v. Seeger, 380 U.S. 163 (1965); Giannella, supra note S, at 1423-31. 
adherents receive a greater share of a government program intended to aid individuals than a minor sect. It is thus apparent that if the estab. lishment clause did no more than incorporate a conventional equal protection value, it would not invalidate equitably allocated aid which produced disparities in benefit.

\section{B. The No-Imposition Value}

The no-preference principle incorporated within the establishment clause is not, however, merely an application of the conventional equality value. It seeks to prevent inequality not only as an inde* pendent, ultimate goal, but as a protection against a possible consequence of inequality: an imposition of religion. Failure to divide an aid-to-religion pie into identical segments is not unconstitutional because it results in $A$ eating more than $B$; that result may be fair and practicable. The danger lies in the fact that $A$ may, and historically has, thrown its pie at $B$, or more accurately, at $B$ 's child. If only the equality value were involved, $B$, not wishing pie or not being able to digest it, should not begrudge $A$ his piece so long as $B$ had the opportunity of participating. But in a pie-throwing contest, keeping ammunition ftom your opponent is as important as having some yourself.

There are two aspects of the imposition danger-one institutional, the other individual. In both cases, the ultimate fear is that government aid will, directly or indirectly, be used to influence choice of religion, not merely to enhance another's exercise. And it is this fear which causes strife and which makes use of the nonbeliever's or otherbeliever's taxes so galling. To the individual, the essential danger is that the family's right to determine the religious beliefs of its members, especially its children, will be undermined, either directly by government imposition of religion or indirectly by government aid to the imposition efforts of religious institutions. Regarding religious choice as exclusively a family affair, ${ }^{105}$ the no-imposition value, in its individual aspect, resolves into a standard prohibiting all aid which presents a substantial danger of imposition of religion.100 To the religious or irreligious institution, the essential danger is that government aid will,

\footnotetext{
105. Although the no-imposition value prohibits government from influencing rell. gious choice, to that extent making religion a private affair, government has a legitimute interest in implementing and encouraging exercise of that private choice, and to that extent, aid to religion serves a public purpose. See pp. 712.13 supra.

106. The universality and intensity of the belief that religious choice should be cx. clusively determined by the family is illustrated by an Isracli law forbidding the coll. version of a minor without the simultaneous conversion of the parents. See Gramont, Jerusalem: Experiment in Coexistence, N.Y. Times, July 30, 1967, § 6 (Magazine), at 14, 20،
} 
by intention or otherwise, favor the proselytizing efforts of a competitor. From the institutional point of view, the battle for adherents could, theoretically, be staged under a no-aid standard or under a standard of identical aid. But since it is impossible to aid all proselytization identically, the institutional interest also resolves into a standard which prohibits all aid presenting a substantial imposition danger.

Almost every Supreme Court Justice who has written an opinion involving the establishment clause has identified no imposition as an establishment value. For instance, Justice Black in McCollum characterizes the violation as aid which enables "religious groups to spread their faith" in violation of the constitutional prohibition upon aid to "the dissemination of ... doctrines." 107 And in Engel he says, "When the power, prestige and financial support of government is placed behind a particular religious belief, the indirect coercive pressure upon religious minorities to conform to the prevailing officially approved religion is plain."108 Justice Frankfurter, concurring in McCollum, identifies the violation as government participation in a program of "religious instruction in a faith which is not that of their [the children's] parents," 109 and Justice Stewart, dissenting in Abinglon, states that the violation is "government support of proselytizing activities of religious sects by throwing the weight of secular authority behind the dissemination of religious tenets." 110 The important question, then, is not whether no imposition is an establishment value, but whether the establishment clause contains any other value 111 and, if not, whether the no-imposition value requires a no-aid standard.

As already discussed, it has been asserted that aid to religion imperils the religious liberty of members of the aided institution. Although this assertion is not persuasive, more substantial questions are raised by the related claim that aid imperils the liberties of nonbelievers and otherbelievers. ${ }^{112}$ That claim relies upon the historical fact that the ascendancy of a religious group has often been associated with the denial of civil liberties to nonbelievers and other-believers. Nor is that associa-

107. 333 U.S. at 210-11.

108. 370 U.S. at 431 .

109. 339 U.S. at 227-28.

110. 374 U.S. at 314. See also Zorach v. Clauson, 343 U.S. 306, 311 (1963) (Justice Douglas speaking for the Court); Illinois ex rel. McCollum v. Board of Educ. 333 U.S. 203, 249 (1948) (dissenting opinion of Reed, J.); Everson v. Board of Educ., 330 U.S. I, 26 (1947) (dissenting opinion of Jackson, J.); Choper, Religion in the Public Schools: A Proposed Constitutional Standard, 47 MinN. L. REv. 329 (1963).

111. See pp. 709-19 supra.

112. Abington School Dist. v. Schempp, 374 U.S. 203, 305 (1963) (concurring opinion of Goldberg, J.); Engel v. Vitale, 370 U.S. 420, 431 (1962); Everson v. Board of Educ., 330 U.S. 1, 53-54 (1947) (dissenting opinion of Rutledge, J.); Katz, supra note 8, at 436. 
tion of only historical validity. Despite the ecumenical movement, it remains true that the supposedly divine source of most religious dogma gives each dogma a claim to exclusive validity which is basically inconsistent with toleration of other beliefs. ${ }^{113}$ And the association is not weakened when a prominent Catholic spokesman asserts that it is the state's duty to promote the true religion, that a Catholic state could not logically permit other groups to engage in "general propaganda," and that constitutional impediments to the view are not insurmountable since "[G]onstitutions can be changed, and non-Catholic sects may decline to such a point that the political proscription of them may become feasible and expedient."114

The threat to civil liberties presented by a dominant religious group was clearly a substantial consideration in the adoption of the establishment clause and it fully supports the accepted view that the clause pro. hibits establishing or preferring a religion. The issue, however, is not exclusive or preferential aid, but any aid. But if equal aid results in unequal benefits and if equal benefits cannot in practice be realized then any aid will increase the power of some churches more than others, and often the church that benefits most is the one which is already closest to dominance. It seems to follow that the best means of avoiding the dangers of dominance is to adopt a no-aid rather than an equal-aid standard. In this context, the real danger of aid to Catholic parochial schools seems to be not that it impairs unity, considered as a state interest, or defeats the Protestant's associational claim, but that it increases the power of the Catholic church, both in absolute terms and in relation to the power of other churches; it is not the Catholic child's absence from a public school that raises constitutional dangers; it is his presence at a parochial school.

The trouble with this position is that it proves too much. The free exercise clause of the first amendment makes religion a constitutional value. Hence, the position must conceive of religion simultaneously as a value and as a threat, the separation principle which includes a noaid doctrine being necessary to maintain equilibrium between them. But what precisely is this supposed equilibrium? Assume that the now only incipient dangers of religion come closer to fruition as a result of the emergence of a dominant and militant religious group in the

113. Cavert, $A$ Response, in The Documents of Vatican II, at 369 (W. Abbott cd. 1966 ).

114. Ryan, Comments on the "Christian Constitution of States," in J. RYAN \& M. Mular, THE State AND THE CHURCh 26, 37-39 (1922), discussed in Katz, supra note 8, at 436. 
United States. In these circumstances, would retention of equilibrium require regulation of the threat? The answer is unquestionably that the free exercise clause forbids any state action against the dominant religious group, at least until first amendment rights of nonbelievers are actually violated. But if equipoise does not require or allow regulation when the threat is imminent, why does equipoise forbid aid at a time when the threat is wholly inchoate? This is not to deny that religion constitutes an incipient danger to the rights of other-believers or that a no-aid principle would do more to mitigate that danger than a principle of equal aid, just as a constitutional prohibition upon religion would be more effective than either. It is to say, however, that in the light of the private and public value of religion, it is better to partially neutralize its incipient dangers by an equal-aid standard than to neutralize them more effectively by a no-aid standard.

The foregoing paragraph seeks to demonstrate that if, in appraising the value of religion against its incipient dangers, a choice had to be made between unrefined no-aid and equal-aid standards, the latter would be preferable. In fact, however, no such choice need be made. Authoritarianism and prejudice correlate with, and may be caused by, religious belief, ${ }^{115}$ and religion may consequently constitute a threat to the rights of other believers. Any aid-equal or unequal-which has the effect of inducing religious belief may therefore increase the total threat. But any such religion-inducing aid offends the value of exclusive parental choice of religion and is consequently invalid under a no-imposition standard. Conversely, aid which does not have the effect of inducing religious belief, but merely accommodates or implements an independent religious choice, does not increase the danger of religion and, since it does not offend the value of parental choice, does not violate the no-imposition standard. Belief in Seventh-day Adventism may pose a threat to the nonbeliever, but the threat only correlates with the growth of that religion. It is not accentuated by aid which merely facilitates its exercise. Mrs. Sherbert's belief in Seventhday Adventism may have made her a greater threat to the rights of non-Adventists than she would otherwise have been; but exempting her from unemployment compensation requirements did not increase that threat. Therefore, regardless of its source and whether coincidental or not, a no-imposition standard seems to serve the value of affording maximum protection to nonbelievers and other-believers from aid which increases the danger of religion; and it appears unnecessary to

115. M. ARGiLe, Religious Behavior 83-85, 87-99 (1958), and studies cited therein. 
resolve definitively the question of whether the establishment clause guarantees nonbelievers and other-believers any greater protection from the incipient dangers of religion than that accorded by an equalaid standard.

A no-imposition standard, then, is consistent with the value of protecting nonbelievers and other-believers from the incipient dangers of religion in situations where government action induces religious belief and in situations where government action implements an independent religious choice without inducing belief. A much more difficult application is the situation where government action, while not inducing belief, has the effect of broadening belief or increasing its intensity. Aid to parochial schools, for instance, will not ordinarily $y^{110}$ have the effect of inducing the adoption of Catholicism; increased parochial school attendance will result, but that follows from implementation of a Catholic family's independent desire to have the child receive religious instruction, not from state action creating that desire. Notwithstanding, a parochial school education, made more attractive by the aid, will or may intensify the child's commitment to Catholicism. ${ }^{117}$ In determining whether that intensification effect might render the aid an establishment violation, we need not consider the value of exclusive parental choice. Since the family has presumably chosen parochial school education for the very purpose of intensifying the child's religious commitment, its rights have not been impaired. Nor need we consider the value of state neutrality in the institutional struggle for adherents. That value is primarily concerned with state action which encourages or facilitates poaching, not with action which tends to make poaching more difficult. But, if religion is adverse to the rights of other believers, does not aid which has the effect of intensifying belief increase the danger, and to that extent, is not the value of protecting other believers from the dangers of religion given something less than maximum protection by a no-imposition standard? Justice Douglas may have the dangers of religion in mind when he warns that the "vice" of aid is that it facilitates "a church's efforts to gain and keep adherents."118

116. It might where the aid resulted in the parochial school's having better educational facilities than the local public school or where it resulted in facilities as good as those in the local public school and thereby attracted non-Catholic whites who wished to avoid a predominant Negro population in the public school. In either of these situations, the aid would constitute an imposition of religion.

117. See M. ARGYLE, supra note 115 , at 43 .

118. Abington School Dist. v. Schempp, 374 U.S. 203, 228 (1963) (concurring opinion) (emphasis added). 
If religion is a threat to the other-believer, the believer's apostasy might be to his advantage. ${ }^{119}$ Even on that assumption, however, the practical alternatives are not commitment versus apostasy but nominal versus devout belief. If there were no parochial schools the total Catholic population would not be significantly reduced. The vast majority of people continue, at least nominally, in the religion they were born to. And the occasional instance of apostasy to which a denial of aid might contribute has no constitutional relevance because the threat to the other believer comes from the totality of a religion's membership, not from any particular believer or handful of believers. The question, then, is whether a devout believer is more dangerous than a nominal believer. There is no certain means of resolving this question, but the evidence points to a negative answer. First, those aspects of a religion's dogma which are most threatening to the rights of other believers are also those most easily learned. It is not necessary to go to parochial school to learn that the Jerws killed Christ. On the contrary, a parochial school education ideally will tend to illuminate Catholic doctrine and thus eliminate intolerances absorbed through casual, uninformed contact. Second, there is substantial authority for the proposition that religious aggression arises not from religious dogma or teaching, but from psychological factors unrelated to religion. To be sure, religion directs that aggression towards the otherbeliever, but a nominal belief may channel aggression equally as well as devout conviction. ${ }^{120}$ Third, empirical evidence indicates that the devout believer (defined, in part, by frequency of church attendance which in turn correlates with early exposure to religious training) is less authoritarian and less prejudiced than the casual, nominal believer. Argyle concludes that although the atheist is less prejudiced and authoritarian than the Catholic, the devout Catholic is less so than his nominal co-religionist. ${ }^{121}$

But perhaps devout belief and nominal belief are not the only alternatives to be considered. Even if devout belief is no more-and perhaps less_-dangerous than nominal belief, and even if the possibility

119. Argyle concludes that atheists and agnostics are least prejudiced and authoritarian-and that Catholics are most. M. ARGYLE, supra note 115. In this connection, however, the important statistic would be a comparison of prejudice and authoritarianism as between Catholics, and agnostics and atheists who formerly were Catholic. No such statistic is available.

120. L. Berkowitz, Aggression: A Sochal Psychological Analysis 132-64 (196\%). See

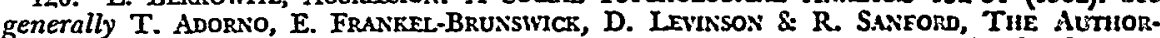
itarian Personality 973 (1950); A. Buss, The Psychology of Aggression 245.59 (1961).

121. M. ARGYIE, supra note 115 , at $83-85,89,93$. 
of outright apostasy is not a significant or benign factor, there still remains the potential for diluting obnoxious religious belief through the cleansing medium of secular public education. In this context, aid to parochial schools would be invalid not because it intensifies belief but because it deprives the state of the opportunity to substitute democratic, scientific and other secular values for obnoxious religious belief. ${ }^{122}$ This analysis provides an explanation for the Catholic Church's firm resolve to continue its parochial school system. In view of the enormous cost, discontinuance might be a reasonable alternative if parochial schools provided merely a more intensified religious instruction than would be provided through other, existing Church programs. If, however, the consequence of discontinuance would be the inculcation of irreligion through the public school curriculum, the church schools must be maintained regardless of cost.

If a prohibition upon state aid to parochial schools is based upon the value of diluting religious belief, the no-aid doctrine can in no sense be characterized as a derivative of a neutral separation principle; rather, it imposes an obligation of hostility to religion. If such a constitutional obligation were incorporated in the establishment clause, government could not aid parochial schools-but neither should it allow them to exist. And certainly it could prohibit their existence. But Pierce $v$. Society of Sisters ${ }^{123}$ affirms their right to exist. Indeed, if the value served by the denial of aid is the dilution of religion, then denial is for the purpose of opposing religion and is itself an imposition. So considered, denial of aid becomes an establishment violation. ${ }^{124}$ Therefore, even accepting the approach that since religion is a danger government may not render aid which increases that danger, that valuc is afforded maximum protection by a no-imposition standard. A standard of no-aid affords no greater protection and is more consistent with hostility than neutrality.

122. Justice Frankfurter's secular unity principle may be a tactful expression of this position; although, like the values purportedly promoted by secular unity, dilution of religious belief might be better accomplished by aid rather than no aid. $A$ public school released time program, for instance, by attracting children away from parochial schools, may better serve to dilute their religious belief than an exclusively sccular public school program which has the effect of maximizing Catholic attendance at parochial schools. See pp. 717-19 supra.

123. 268 U.S. 510 (1925).

124. "We agree of course that the State may not establish a 'religion of sccularism" in the sense of affirmatively opposing or showing hostility to religion, thus 'preferring those who believe in no religion over those who do believe." "Abington School Dist. v. Schicmpp, 374 U.S. 203, 225 (1963). See also pp. 700-01 supra. 
C. Content and Applications of a No-Imposition Standard

1. Imposition Distinguished from Implementation

A no-imposition standard assumes that the principal purpose of the establishment clause is to guarantee to an individual adult maximum freedom in the determination of his religious or irreligious beliefs, and to protect the primacy of the parents in the determination of their children's religious or irreligious beliefs. Other purposes may be to guarantee governmental neutrality in the institutional battle for adherents and to prohibit aid which increases the dangers of religion to the rights of nonbelievers or other-believers. All of these purposes are accomplished by a standard which does no more than prohibit government from compelling or influencing religious choice and from aiding others to influence religious choice.

In some respects a no-imposition standard produces results under the establishment clause which overlap with results reached through application of the free exercise clause. Thus, a statute forbidding Baptist church services would prohibit free exercise and would also influence religious choice. In other respects the overlap is questionable. Compelling a Baptist to attend Seventh-day Adventist services, but allowing him to attend his own, is certainly an act influencing religious choice but-assuming that Baptist dogma allows its membership to attend the services of another sect-may not be a prohibition of free exercise. In still other respects there is no overlap at all. State sponsorship of prayer for those schoolchildren who wish to pray is not a prohibition of the free exercise rights of nonparticipating schoolchildren ${ }^{125}$ but does influence their religious choice. A no-imposition standard makes it unnecessary to decide whether particular state action constitutes coercion. Compelling religious participation is certainly an imposition, but so is persuasion, endorsement or any other means of influencing choice. ${ }^{126}$

125. Engel v. Vitale, 370 U.S. 421,430 (1962); Abington School Dist. v. Schempp, 374 U.S. 203,223 (1963).

126. Professor Brown points out that both the free exercise and establishment clauses are applicable to the states only insofar as their violation constitutes a deprivation of life, liberty or property under the fourteenth amendment. Brown, supra note 85, at 25. It is therefore illogical to hold that a voluntary prajer program is not a violation of the free exercise clause because it does not involve coercion but is a violation of the establishment clause which does not require coercion; if influence does not constitute a deprivation of religious liberty, in logic it cannot constitute a deprivation of whatcier liberty is protected by the establishment clause. A better means of resolving the problem is to hold that influence is a deprivation of liberty in both situations, but that frce exercise only protects the liberty to exercise one's own religion; it does not protect against influence or compulsion subjecting one to the teachings of another religion when that 
To be distinguished from imposition is state action which does not influence choice but helps implement a religious or irreligious choice independently made. In rendering such aid the state is expressing a judgment that religion is a worthy activity, and it may be argued that in recognizing worthiness, the state is by design or otherwise encouraging belief and hence influencing religious choice. As a practical matter, however, recognition of worth will not have a substantial imposition effect and will have no effect at all where the religion aided is a minority sect. Exemption of Mrs. Sherbert from South Carolina's unemployment compensation requirement represents a judgment that the exercise of Seventh-day Adventism is more worthy than bowling on Saturdays, but the exemption has no significant effect and arguably no effect at all upon whether someone becomes a Seventh-day Adventist. Similarly, the Sabbatarian exemption from Sunday closing laws does not induce one to become a Jew; draft exemption to conscientious objectors does not normally induce one to become a Quaker; closing the public schools on all religious holidays or on every Wednesday at 2 P.M. does not induce the adoption of religion; and compulsory Sunday closing, while implementing an independent desire to attend church services, has no substantial effect upon the creation of such desire. The availability of preferential aid to religious exercise may, to be sure, induce false claims of religious belief, but the establishment clause is not concerned with false claims of belief, only with induced belief. ${ }^{127}$

Some aids to religion, whether preferential or nonpreferential, may have the effect of intensifying an independently made religious belief. While a parochial school bus subsidy does not induce adoption of Catholicism, it may result in a more intense belief. But, as already noted, action which has the effect of intensifying belief is qualitatively different from action which induces belief; the former supplements while the latter contradicts the establishment values of individual and family determination of religious choice. Perfect neutrality is impossible: implementation of a desire to attend parochial school may intensify belief, but failure to implement defeats religious choice; and since freedom of religious choice, not neutrality per se, is the fundamental establishment value, the neutrality tool is useful only insofar as it promotes that choice.

is not forbidden by the body of dogma of one's own religion. The latter is an individual, parental and institutional liberty distinct from free exercise and it is that distinct llberty which is protected by the establishment clause.

127. Cf. Sherbert v. Verner, 374 U.S. 398, 407 (1963). 


\section{Imposition and Balancing}

Government implementation of one individual's religious choice may result in the imposition of religion upon another. That was the relationship involved in the released time, and Bible and prayer reading cases. ${ }^{128}$ To the extent that the children involved, or their parents, desired religious instruction, there was merely implementation of an independently made religious choice. That implementation, however, may have had an imposition effect on those children whose parents did not desire instruction. For these purposes, it is not necessary to decide whether the Court's psychological conclusions as to factors which influence children were correct, or whether the psychological conclusions of McCollum are consistent with those of Zorach. The important point is that all four decisions are primarily concerned with whether the practices in question would have an imposition effect. Thus, significantly, Justice Douglas said in Zorach that the state could "encourage," "accommodate," or "cooperate" with religious exercise, but could not "persuade or force," that is, could not impose religion.120 These decisions make clear that implementation and imposition effects are not to be balanced. Religion in the classroom-whether by way of instruction or observance-may fairly be said to advance or implement the majority's free exercise. At the same time, perhaps only a few children were subjected to a threat of religious imposition. A balancing standard, therefore, would have yielded different results in Abington, Engel and McCollum. But the Court evidently considered that the balance would have been between the majority's worthy but nonconstitutional religious interest and the minority's constitutional right.

A much more difficult problem would arise if the majority could not possibly exercise its religion without an imposition of that religion upon the minority. In that event a true collision between constitutional imperatives would occur and subordination of one claim to the other would obviously be required. Should such a situation exist it is far from certain that the establishment clause would be the one subordinated. In fact, however, if the establishment clause is read to prohibit only an imposition of religion, the likelihood of any collision between free exercise and establishment is substantially reduced and the subordination problem becomes largely theoretical. The instances cited by Justice Brennan, for example, as representing a subordination

128. Abington School Dist. v. Schempp, 374 U.S. 203 (1963); Engel v. Vitale, 370 U.S. 421 (1962); Zorach v. Clauson, 343 U.S. 306 (1952); Illinois ex rel. AicCollum v. Board of Educ., 333 U.S. 203 (1947).

129. 343 U.S. at 311,314 . 
of establishment to exercise, ${ }^{130}$ are situations where there has been no imposition, and hence no establishment violation to be subordinated.

An imposition standard also better explains situations where an aid to religion is purportedly balanced against advancement of a state secular interest. Since Everson and McGowan, ${ }^{131}$ which involve this approach, do not identify the evil associated with aid they make intelligent balancing impossible. If the evil is identified as imposition, however, these cases become manageable. Implementation of independent decisions to attend parochial school or Sunday church services does not result in any imposition of religion. Since they are not impositions, they do not raise any establishment question and no balancing is required.

Chief Justice Warren in McGowan almost sees this. After seeking to demonstrate that Sunday closing is secularly motivated, he distinguishes McCollum: "[N]o such coercion to attend church services is present in the situation at bar . . . the alternatives open to nonlaboring persons in the instant case are far more diverse." 183 In thus distinguishing McCollum, the Court's opinion seems to suggest that even if the state's motivation is secular, a regulation which has the effect of compelling or influencing religious choice is suspect. In other words, a secular motive does not necessarily justify an imposition effect. But if the establishment violation consists of an imposition effect, what relevance does that clause have to a situation where there is no imposition, whether the state's motive be secular or religious? Conversely, where imposition results, only a compelling secular purpose which may not otherwise be accomplished would over-balance the prima facie establishment violation.

\section{Imposition by Government Distinguished from Indirect Aid to Private Proselytization}

Under a no-imposition standard, aid which implements religious exercise without inducing religious belief is lawful. Conversely, any direct government imposition of religion, whether the motivation be secular or religious, is unlawful. Situations in both of these categories may be resolved without use of any balancing technique. There is, however, a third category: government aid, designed to serve a secular

180. Abington School Dist. v. Schempp, 374 U.S. 203, 299 (1968) (concurring opinion of Brennan, $\mathrm{J}$.); see p. 707 supra.

181, Everson v. Board of Educ., 390 U.S. 1 (1947); McGowan v. Maryland, 866 U.S. 420 (1961).

132. 366 U.S. at 451 . 
interest or to implement religious exercise, which has as an indirect effect the advancement of private proselytizing efforts; and situations arising therein require a balancing standard.

There is a difference between imposition by government and government aid to private proselytization which justifies a per se rule in the former case and a balancing approach in the latter. Direct government imposition is much more effective than private proselytization, and hence much more to be feared and guarded against. The state's traditional role is not that of an interested advocate, frankly attempting to persuade, but of an arbiter of truth. The nonbeliever or other-believer is therefore much more subject to imposition by governmental advocacy, unavoidably disguised as objective truth, than by the blandishments and imprecations of a private institution. Justice Brennan offers an analogous distinction as a means of reconciling McCollum and Zorach:

The deeper difference was that the McCollum program placed the religious instructor in the public school classroom in precisely the position of authority held by the regular teachers of secular subjects, which the Zorach program did not. The McCollum program, in lending to the support of sectarian instruction all the authority of the governmentally operated public school system, brought government and religion into that proximity which the Establishment Clause forbids. To be sure, a religious teacher presumably commands substantial respect and merits attention in his own right. But the Constitution does not permit that prestige and capacity for influence to be augmented by investiture of all the symbols of authority at the command of the lay teacher for the enhancement of secular instruction. ${ }^{133}$

That is, in McCollum the state associated itself with the religious instruction program sufficiently to assume a proselytizing role whereas in Zorach the absence of such association resulted in a characterization of the program as one of state aid to private religious instruction rather than imposition by government.

A striking illustration of the distinction between imposition by government and aid to private proselytization is afforded by a com. parison of Fowler $v$. Rhode Island ${ }^{134}$ and McCollum. In Fowler the municipality was not only permitted but required to allow Jehovah's Witnesses use of park facilities to spread their gospel, while in MCCollum the use of school facilities for religious instruction purposes

133. Abington School Dist. v. Schempp, 374 U.S. 203, 262.63 (1953) (concurring opinion). 134. 345 U.S. 67 (1952). 
was held unconstitutional. In both cases aid limited to use of public facilities would have been lawful, especially in McCollum since the religious groups there did not intend to proselytize but only to offer religious instruction to their own members. In $M c$ Collum, however, the state associated itself with the program and thereby influenced attendance, while in Fowler the unrestricted range of choices available, the lack of peer pressure and the absence of any aura of state authority precluded the possibility that the state itself was influencing religious choice. ${ }^{135}$ This is not to say that aid to private proselytization is a proper purpose. On the contrary, it is never a proper purpose and always creates a prima facie establishment violation, but that violation may sometimes be overcome by a secular purpose, or by a free exercise or equality right, or by a free exercise claim other than the institution's interest in proselytizing. ${ }^{136} \mathrm{It}$ is interesting to compare $\mathrm{McCollum}$ and Fowler with the practice of allowing religious institutions to instruct their members in public buildings, after hours. In McCollum there was state imposition-hence an absolute standard is employed; in Fowler there was state aid to private proselytization-hence the imposition effect of the aid is balanced against a countervailing interest, specifically, in Fowler, a free exercise and equal protection right. Where, on the other hand, public facilities are used for a nonproselytizing religious purpose and there is no danger of an unintended imposition effect, there is not even a prima facie violation-hence there is no need to find a countervailing interest justifying the aid.

The distinction sometimes made betwen aid to the institution and aid to the individual ${ }^{137}$ often produces results consistent with those obtained pursuant to a no-imposition standard. This occurs primarily because many of the benefits conferred upon individuals on the basis of their religious beliefs are in the form of exemptions from regulatory laws, which are unlikely to present imposition dangers, and because individuals-as individuals-are usually not in the business of proselytizing and hence are not likely to devote the aid they receive

135. The same distinction reconciles McCollum with Follett v. McCormick, 321 U.S. 573 (1944), and Murdock v. Pennsylvania, 319 U.S. 105 (1943). Cf. Kurland, supra note 7, at $48-49$.

136. Justice Reed, speaking for the Court in Jones v. Opelika, 316 U.S. 584 (1942), rev'd on rehearing, 319 U.S. 103 (1943) (per curiam), held that tax exemption for prosely. tizing activities was not constitutionally compelled but indicated that such an excinption would be a permissible exercise of legislative discretion. Id. at 598. This seems to mean that the constitutional evil may be overcome by a purpose to effect that evil. To that extent, the case is inconsistent with a no-imposition standard.

137. Abington School Dist. v. Schempp, 374 U.S. 203, 302.03 (1963) (concurring opinion of Brennan, J.); Cushman, Public Support of Religious Education in American Constitutional Law, 45 ILL. L. REv, 333, 387-49 (1950). 
directly to a proselytizing use. The distinction, however, has no intrinsic merit; it will achieve correct results only insofar as its applications fortuitously coincide with those reached pursuant to a no-imposition standard. Thus a state grant to individuals who regularly attend church is clearly an imposition of religion and would probably be universally considered an establishment violation, yet it is an aid to an individual, not to an institution.

Conversely, many grants to religious institutions would not present any immediate imposition danger. For instance, state subsidy of parochial school textbook purchases, whether secular or religious books, ${ }^{138}$ would not impose religion on the parochial school child. The only immediate effect would be to implement a private desire to obtain a religious education. The difficulty is that an indirect effect of institutional aid which has financial value may be the imposition of religion, since funds freed by the aid may be diverted to a proselytizing use. ${ }^{139}$ But such diversion is a possible, if more remote, result of financially significant aid to the individual. Consequently, the institution-individual distinction at best serves only as a rule of thumb indicating the likelihood of diversion into a proselytizing use and adds nothing but obfuscation to a no-imposition standard.

Justice Douglas, concurring in Abington, identifies imposition as the evil of aid. Moreover, he sees no constitutional distinction between "the State itself ... conducting religious exercises" (imposition by government) and aid, direct or indirect, in large or small amounts, to the proselytizing efforts of private institutions. ${ }^{110}$ As already noted, there is a significant difference in imposition effect as between government imposition and aid to the proselytizing function, although that difference does not automatically create a constitutional distinction. But, if no such distinction is made, how is fire or police protection justified? Both have financial value and hence may be said to constitute indirect aid to proselytizing efforts of private institutions. They are not necessarily justified by a transcendent equality value. As we have noted, ${ }^{141}$ equality must at times be subordinated to establishment in order to avoid direct and substantial imposition effects. Obeisance to

138. It has been suggested that aid to parochial schools is unconstitutional because those schools make religious use of even secular materials. Gordon, supra note 70, at 90 . But religious use for those who wish religious use is not antithetical to any constitutional value.

139. Christianity Today, Mar. 17, 1967, at 41; see Christian Science Monitor, Apr. 27, 1966, at 1 , col. 3.

140. 374 U.S. at 229.30.

141. See pp. $698-99$ supra. 
equality compels disregard for the difference between aid which presents a likelihood of a substantial imposition effect and aid which presents at most a minimal possibility of a marginal imposition effect; and yet the greater and more likely the effect, the greater the danger the establishment clause is intended to prevent. Therefore, notwithstanding Justice Douglas' view that an establishment is an establishment, it is necessary to include within a no-imposition standard a distinction between government imposition and government aid to religious institutions not intended to further their imposition efforts but which may be diverted to that purpose. The constitutionality of aid which falls within this latter category must be determined by balancing. Recognition that no imposition is the establishment value, however, allows a more structured application of that inherently uncertain methodology. Although it contributes no new insight into those factors (state secular interest, equality value and free exercise right or claim) which may serve to overcome a prima facie violation, it identifies the nature of that violation and thereby allows for assessments and gradations of the degree of permissible danger.

A number of factors are relevant to an assessment of the imposition danger.

The first and most important is the extent to which the aid will directly serve a proselytizing use. For instance, employment of religious institutions as instrumentalities or conduits of public welfare programs $^{142}$ will result in direct aid to their proselytizing function. Proselytization in such situations is not a possible, indirect result brought about by diversion of funds but the probable, perhaps in. evitable, consequence of their intended use. A church will more effectively influence religious choice by administering poverty funds than by a millenium of conventional evangelism with exclusively "re. ligious" materials. ${ }^{143}$ Most obviously, responsibility for the administri-

142. Religious and religious-affiliated organizations participate in an enormots number of such federal programs. See, e.g., Housing: (a) Housing Act of 1959, § 202, 78 Stat, 667, as amended, 12 U.S.C. § 1710 (Supp. I, 1965); (b) National Housing Act, \& 221(d)(8), 7f Stat. 149, as amended, 12 U.S.C. \& 1715(l) (Supp. I, 1965); (c) 12 U.S.C. 1701(s); (d) Housing Act of 1961, § 207, 75 Stat. 165, as amended, 12 U.S.C. § 1713 (Supp. 1, 1965); Child Welfare: Social Security Act, tit. V, 42 U.S.C. $\$ \$ 701-31$ (maternal child health and crippled children's services); Juvenile Delinquency: 42 U.S.C. \& 2541; Eiconomic Opportunity: (a) Economic Opportunity Act of 1964, tit. II, 78 Stat. 516, as amended, 42 U.S.C. §§ 2782 et seq. (Supp. I, 1965) (community action); (b) id. tit. II, pt. B, 78 Stat. 520, as amended, 42 U.S.C. $\$ \$ 2802$ et seq. (Supp. I, 1965) (adult basic cducation); (c) ill. tit. I, pt. B, 78 Stat. 512, as amended, 42 U.S.C. $\$ \$ 2734-85$ (Supp. I, 1965) (work training program). For a compendium of programs in which church groups participate, sce Hear. ings, supra note 20 , at $12-22$.

143. See note 20 supra. 
tion of poverty funds will enable a church to reach a vast audience otherwise unreceptive to its teachings. A few churches will consciously seek to gain new members from that audience, and though most churches will not, some of their individual clergymen will. More significantly, participation will gain for the church an image of "relevance" which in turn will attract members.14t And, most significantly, independently of any policy of gaining members, most clergymen-administrators believe that those in their charge have spiritual as well as material needs and that failure to satisfy all of those needs is a disservice to the poor. It is theoretically possible to separate material from spiritual service, but that separation is unnatural and requires constant discipline of which few are capable. The clergymen-administrators who fail to maintain that separation are not malevolent evangelists: they are merely well-intentioned human beings unable to perform an unnatural, but constitutionally required duty.

A second relevant factor is the extent to which aid to the proselytizing function, or aid which may be converted into a proselytizing use, may at least theoretically be shared equally by all religious and irreligious groups. An exemption for religious proselytizers from a street vending tax obviously aids the Jehovah's Witness Church more than the Catholic Church, but that inequality of benefit results from the different proselytizing techniques those churches have chosen to adopt. Every group could, if they chose, benefit equally from the exemption. A property tax exemption, on the other hand, frees more money for proselytizing use to the wealthy church than to the poorer ones, and that discrimination is not a product of choice. An exemption limited to $\$ 5,000$ of church property would obviously be less discriminatory.

A third factor is the likelihood that aid to a nonproselytizing use will be converted into a proselytizing use and the magnitude of the funds involved. A requirement that the funds granted not be used for proselytization is obviously insufficient. A requirement that the total amount of annual church appropriations for proselytization not be increased would be impossible to administer and constitutionally defective. The only test, and a difficult one to apply, which would sometimes be practicable is whether the activity aided was one which

144. See remarks of Senator Charles Percy, reported in Wall Street Journal, July 31, 1967, at 9, col. 1: "The church which remains aloof [from social welfare programs] . . . will remain irrelevant to millions of Americans, and especially to young Americans": N.Y. Times, Jan. 2, 1968, at 48, col. 3 (report that the failure of Orthodox Judaism to become involved in such social issues as poverty has disenchanted some of the most devout members). 
the religious institution was already paying for or was likely to pay for. If, for instance, parochial school children had always themselves paid for their lunches or books, a grant to the institution or the children for those purposes would be less likely to create funds for proselytizing. A grant or loan of a cyclotron to a small denominational college is a clearer case. In considering the magnitude of freed funds, a de minimis concept is obviously called for. One hundred or one thousand dollars will have no meaningful imposition effect.

Applying a balancing standard to grants to religious institutions for public welfare purposes, we thus suggest three factors which point toward an imposition danger: (1) most significantly, a direct aid to a proselytizing function, (2) a variety of aid which many, perhaps most, sects are not economically or organizationally able to participate in, and (3) aid of substantial dollar magnitude which may facilitate diversion of funds for additional proselytizing use. Conversely, the only factor to be balanced against the substantial imposition danger is that some religious institutions are effective administrators of such programs. Neither the equality value nor any free exercise claim or right is defeated by denying church participation. ${ }^{145}$ Therefore, unless church participation is vital to the success of public welfare programsbecause private secular institutions are not equipped to administer them and because there is a compelling need for private rather than public administration-that participation would seem to be violative of the establishment clause.

The case for aid to parochial schools, under a balancing standard which identifies imposition as the establishment danger, is much stronger. Most importantly, parochial school aid does not directly serve a proselytizing function; for the most part, only existing Catholics who wish a religious education are directly affected. The imposition effect, if any, will only result from the possible diversion of funds for a proselytizing use, ${ }^{146}$ and it is not at all clear that such diversions will occur. If parochial school facilities are as deficient as alleged, it is not likely that a government subsidy will result in a diminution of institutional appropriations to education. Failure to

145. See pp. $698-99$ supra.

146. Such being the case, it should not make any difference whether the aid is granted to parochial grade schools or universities. The only circumstance which would justify that distinction is the possibility that intensified belief increases the danger of Cathol. icism to non-Catholics. If such were the case, it would be arguable that a university religious education is qualitatively less dangerous than a grade school religious cducation. The evidence, however, indicates that intensified belief does not increase the danger of religion. See pp. 724-26 supra. 
subsidize might ultimately result in an increase in the percentage of church funds used for education, thereby curtailing funds available for proselytization, but it is also possible that failure to subsidize will make parochial education an impossible financial burden, ${ }^{127}$ thereby freeing education funds for proselytizing use. Consequently, while it is true that Catholic schools will benefit far more than other religious schools from an education subsidy, and that the sums involved are very substantial, the likelihood of a significant imposition effect resulting from a subsidy is at best speculative. Offsetting this speculative danger is the obvious state interest in quality education for all children and the parochial school child's equality, free exercise and establishment claims. ${ }^{148}$ Therefore, it would appear that a no-imposition standard would validate a parochial school subsidy, and that result is clearly indicated if we may use as a touchstone practices, such as tax exemption, which pose much graver imposition dangers ${ }^{140}$ and yet have been held constitutional. ${ }^{150}$

147. Chiristianity Today, Mar. 31, 1967, at 39; N.Y. Times, Sept. 10, 1967, \& 1, at 75, col. 2. See also id., Sept. 20, 1967, § 1, at 34, col. 6; id., Jan. 11, 1967, § 1, at 37, col. 2. 148. See pp. 699-701 supra. As stated in note 138 supra, there is no greater imposition danger from a subsidy for religious books than from a subsidy for secular books. It may be, however, that there is a distinction in that failure to subsidize religious bools does not frustrate any state secular interest or the religious child's equality and establishment claims. Thus, in such a case, only the child's free exercise claim is properly to be balanced against the speculative, indirect imposition danger.

149. In tax exemption there is no similarity in benefit, the vealthier churches in effect receiving more money, the funds inrolved are unrestricted in use and consequently may be directly used for proselytizing, and the amount of money involved may be sub. stantial. At the same time no secular purpose is necessarily served since there is no restriction on the use to which the funds may be put and refusal to grant the exemption would not deprive religious individuals of any equality claim. Thus, at best, only a marginal free exercise claim may be balanced against the substantial imposition danger. 150. See Murray v. Comptroller of the Treasury, 241 Mfd. 383, 216 A.2d 897, cert. denied, 385 U.S. 816 (1966). 


\section{The Yale Law Journal}

Volume 77, Number 4, March 1968

\author{
Editor-in-Chief \\ Note \& Comment \\ Editors
}

Article \& Book

Review Editors

Topics Editor

Managing Editor

Richard Ayres

Michael Barone

KENNETH C. BASS III

Joseph C. BeLL

JaMES T. BetTs

R. David Broiles

William A. Butler

Charles Cannon

ALEXANDER CAPRON

Barry Garter

RIGHARD COTTON

Geoffrey DrURY

Copy and Publication Manager

Business Manager

Business Secretaries
WILLIAM D. IVERSON

LEONARD H. BECKER

THOMAS C. GREY

RICHARD S. MaRKovits

JEFFREX S. WOOD

Russell H. Carpenter, Jr.

ERIC SCHNAPPER

Charles H. Whitebread II

R. JAMES WOOLSEY

John F. Dienelt

STEPheN S. DunhaM

RXCHARD A. EPSTEIN

W. JOHN GLANCY

Julian Dean Heller

GARY N. JAGOES

MXCHAEL JEFFERX

ALAN KaUzer

ThOMAS M. Lemberg

LINDSAY LOVEJOY

David B. LXTLE

Victor MarRero

JOHN C. ROBERTS

HAMILTON OSBORNE, JR.

M. Olive Butterfield, Pamela S. Willmoti'
Angus C. MACUETII

HAMILTON Osnorne, JR.

JOHN C. ROBERTS

LEONARD RUDINOWTTZ

DAvid SGHoendzod

StzVEN L. SLOCA

JAMES G. SPETH

MiCHAEL T. STAPLETON

JoEL W. StERnMaN

EDWARd L. StrohineHN, Jr.

RICHARD ZiMMER

MatThew ZWERLing

Student Contributors to This Issue

R. David Broiles, Loyalty Oaths Are Not Dead-At Last Report One Was Alive in New York

Barry Carter, Effective Guaranty of a Speedy Trial for Convicts in Other Jurisdictions

Joel W. Sternman, Collective Bargaining Agreements and State Antitrust Immunity 